\title{
William Cameron Chewett and W.C. Chewett \& Company of Toronto, Printers and Publishers
}

Donald W. McLeod

WILliaM CAMERON CHEWETT PLAYED A RELATIVELY BRIEF, BUT IMportant role in the history of Canadian printing and publishing. A man of many talents, he was virtually forgotten when he died in 1897 . Little has been written about him or W.C. Chewett and Company, and much of the published information concerning Chewett, scattered throughout various sources, is either confused or erroneous. This paper proposes to remove some of this confusion and obscurity by examining Chewett's career and the contribution made by Chewett and Company to Canadian printing and publishing between I86I and I869.

W.C. Chewett was the scion of one of Toronto's most prominent and influential families. His grandfather, William Chewett, came to Canada in I77I and served as an engineer in the defence of Quebec in 1775-76. In 179r he was appointed deputy surveyor-general of Upper Canada. Much of what is now the province of Ontario was first surveyed by William Chewett, who, with Thomas Ridout, later became joint surveyor-general. Chewett and his family were early pioneers of 'Muddy York,' where, as an honorary Colonel in the Militia, Chewett played an important role in the defence of the town during the American invasion of 1813 . In his later years, he held the position of registrar of the Surrogate Court. William Chewett retired from public service in 1832 and died in $1849 .^{1}$

His son, James Grant Chewett, had no less an illustrious career. Born in 1793, he followed in his father's footsteps as a surveyor and became the principal surveyor and draftsman in the surveyor-general's office. ${ }^{2} \mathrm{He}$ was also a builder and designed a number of structures in Toronto including the third Provincial Parliament buildings. J.G. Chewett was a city alderman in I838-39 and Vice-President of the Bank of Upper Cariada for several years. Later, he became the first President of the Bank of Toronto, a position he held until his death in $1862 .^{3}$

When we consider the distinguished careers of his father and grandfather, it is not surprising that William Cameron Chewett was once called 'a Canadian of Canadians. ${ }^{4}$ He was born in York, U.C., on 16 August 1828 and received a fine education, first at Upper Canada College and later at King's College and 
the University of Toronto. Chewett was a matriculated student at King's College, Toronto, in 1845 , and he went on to study medicine there. He was a keen student and was awarded first prize in 'Anatomy and Physiology' (I848), in 'Medicine' (I848), in 'Surgery' (I849), and in 'Medical Jurisprudence' (1849).. Chewett completed his studies in medicine at the University of Toronto in I85I, the year after its incorporation. His was indeed the first graduated medical class at the University of Toronto, but the claim that he was the first medical graduate at this university was not entirely true, as the honour was shared with another student, C.S. Eastwood. ${ }^{6}$

How did a medical doctor become involved in Toronto's early printing and publishing trade? Although he was often referred to as Dr. Chewett, W.C. Chewett never practised as a medical doctor, preferring instead, in the words of William Canniff, to find 'more congenial occupation.' David Sinclair, in his paper 'The First Pirated Edition of Tennyson's Poems,' claimed that Chewett was a man with literary inclinations and that he became involved with the Anglo-American Magazine between 1852 and I $855 .{ }^{8}$ An examination of the first five volumes (I852-I854) of this magazine, however, throws no light on this claim; there are no works signed by Chewett. A connection between Chewett and this publication would be very interesting, as it was published by Thomas Maclear.

Maclear's printing, publishing, and bookselling business originated in 1838 , when it was established by Hugh Scobie. When Scobie died in 1853, Maclear purchased part of the business from his widow. During the 1850 os Maclear's firm was an important printing and publishing concern, which turned out a variety of works including the Canadian Almanac and the Upper Canada Law Journal." There is some confusion as to when W.C. Chewett joined Maclear's firm. H. Pearson Gundy has claimed that Chewett was taken into partnership by Maclear in about $1856,^{10}$ while Elizabeth Hulse has simply stated that he was working at Maclear and Company in $1859 .{ }^{11}$ The City of Toronto Tax Assessment Rolls for the Ward of St. Lawrence are not much help in this matter either. The yearly tax assessment was conducted in the autumn, usually in September. ${ }^{12} \mathrm{Up}$ to the assessment for 1858 , only the name of the company occupying a certain address (in this case 17 and I9 King Street East) was listed. The assessment rolls after this time listed the company's name as well as employee names and their positions at the firm. For the assessment of 1858 , W.C. Chewett's name was listed. ${ }^{13}$ Perhaps the most important source regarding the date of Chewett's first employment at Maclear and Company is a short biographical portrait of William W. Copp that appeared in the July I89I issue of Books and Notions. This article stated that 'in I854 Mr. Copp formed a partnership with Thomas Maclear and W.C. Chewett. ${ }^{\prime 14}$ As this was written when all three men were still alive, there is some reason to believe that this information may be correct and that Chewett was working at Maclear and Company by at least I 854 . 
Chewett undoubtedly spent his first years at Maclear and Company learning the intricacies of printing, publishing, and the retail trade. It was not long, however, before he took a more active role in the business. The Books and Notions portrait of Copp also stated that Maclear retired in I857. ${ }^{15}$ This did not mean retirement in a permanent sense. Maclear became active in the wholesale book trade and continued publishing well in to the $188 \mathrm{os}$, although not at 17 and I9 King Street East, as Gundy suggested, but at the old Manson firm at 17 King Street West. ${ }^{16}$ It is clear, in any case, that by the autumn of 1858 Maclear was no longer associated with his old partners, Chewett, Copp, and George E. Thomas. This is substantiated by the City of Toronto Tax Assessment Roll for 1858 , which lists the occupants of 17 and I9 King Street East as 'Wm. C. Chewitt [sic] Wm. W. Copp' - Stationers' and 'Thomas Co., G.E. Thomas - Publishers. ${ }^{17}$ There is no mention of Maclear.

This juggling of the partnership invites confusion. By 1858 , however, there is little doubt that Chewett had become the senior partner in the firm, even though the 'W.C. Chewett and Co.' imprint was not used until at least I86I. ${ }^{18}$ Chewett's dominance at this time may seem odd when we consider that W.W. Copp had much more experience in the business; he had started work at Hugh Scobie's in $1842 .{ }^{19}$ The fact that Chewett became the senior partner likely reflects the relative size of his investment in the company.

By 1859 George Thomas had left 17 and ig King Street East. ${ }^{20}$. Chewett and Copp continued alone in partnership until I862, when Henry J. Clark became a partner in W.C. Chewett and Company. Clark had worked as a clerk at Maclear and Company from the mid-I85os. There is some confusion as to when he joined the partnership with Chewett and Copp, and this arises principally from Copp and Clark's registration of partnership in 1870 , which stated that their partnership had existed since I April I863. This has been interpreted as a reference to their partnership with Chewett, ${ }^{21}$ but both the I89I Books and Notions article regarding W.W. Copp and the city tax assessment rolls clearly show that the three became partners in $1862 .{ }^{22}$ In the tax assessments for I859 and I860, Clark was listed as being on 'income,' ${ }^{23}$ while in the assessment for I86I he was listed simply as a 'clerk.'24 The assessment for 1862 , on the other hand, clearly grouped him as being in a partnership with Chewett and Copp. ${ }^{25}$

Chewett and Company was a fairly large business concern housed in a three-storey brick building, with the retail outlet on the ground floor and the factory on the upper stories. As early as I86I, the company's advertisements stressed the variety of goods and services offered; they were stationers and paper dealers, general booksellers, printers, lithographers, and bookbinders. ${ }^{26}$ W.C. Chewett and Company would publish works as well as print them. An emphasis was placed on the modernity of equipment used by the firm, particularly the steam-powered printing press. Special pride was taken in announcing the lithographic capabilities of the company. Their considerable 
skill in executing '... in the best style, on the most reasonable terms and with dispatch every description of Lithography, and Steel and Copper Plate Printing ... ${ }^{27}$ was best demonstrated in the company's own Christmas Catalogue for 1865 , which contained a number of handsome illustrations. ${ }^{28}$

Between the years I862 and I867, the lithographic work of Chewett and Company made a very favorable impression at the annual Upper Canada Provincial Exhibition; in each of these years they won first prize for the 'Best Lithographic Drawing, Plain,' and from I863 to I867 they also won for 'Best Lithographic Drawing, Coloured.' In addition, the company received numerous other awards for 'Specimens of Commercial Lithography,' 'Best Frame of Lithographed Cheques, and other categories. ${ }^{29}$ Many of these successes may have been due to the skill of Charles Fuller. Fuller had been a partner in Fuller and Bencke, a major lithographic firm in Toronto between I 858 and I862, and was the force behind several of their creditable productions, including a chromolithograph of one of Paul Kane's Indian scenes. About r862, Fuller and Bencke was purchased by Chewett and Company, and Fuller became manager of Chewett's lithographic department. ${ }^{30}$

The retail branch of W.C. Chewett and Company did a very large volume of business, as there were still relatively few large firms engaged in the retail book trade in Toronto in the I86os. Chewett's became one of the best-known businesses in Canada; 'the firm's store was a meeting place, a sort of rendezvous where people from all parts of the country would make engagements by letter to meet each other and would turn up there in crowds. ${ }^{\prime 31}$

In addition to being a social attraction, W.C. Chewett and Company was one of Canada's most important printing and publishing firms during the I86os. The company's output was quite large and varied (see Appendix One), but included few 'literary' works. One important exception to this was their printing in 1862 of the first pirated edition of Tennyson's early poems. ${ }^{32}$ Most of the firm's imprints, however, were of a 'practical' nature, and included railway gazetteers, works on religious topics, geological studies, and educational textbooks. Chewett and Company published several local directories and continued publication of the Canadian Almanac, which had been established by Chewett's predecessors, Hugh Scobie and Maclear and Company. The company also printed several periodicals, including the Canadian Independent and the Journal of the Board of Arts and Manufactures of Upper Canada.

Law and medical books appear to have been a specialty of W.C. Chewett and Company. They published a number of important books dealing with the law, including John McNab's The Magistrate's Manual ... (1865), Robert Sullivan's A Handy Book of Commercial Law, for Upper Canada (1866), and Samuel George Wood's The Registry Act of 1865 (1866). Such works were important in a city that had long been the centre for the provincial law courts. In addition, Chewett's own medical background may have secured the publication of a 
few important titles in the field of medicine, including The Medical Register for Upper Canada, 1867.

W.C. Chewett and Company also published a number of works of general interest, including at least one volume that would be known today as an 'instant book.' In order to take advantage of recent events, Chewett's issued The Fenian Raid at Fort Erie, June the First and Second, 1866 ..., which was simply a compilation of material from newspaper reports in the Globe, Leader, and Telegraph, with additional notes and remarks from eyewitnesses. $^{33}$

David Sinclair was correct when he stated in his article on the Tennyson forgery that the 'backwoods' Canadian printers and publishers of this time were capable of producing items of creditable workmanship. ${ }^{34}$ Most of the Chewett and Company imprints that survive contain little decorative printing. As Sinclair pointed out, many of the monographs they printed had only a relatively simple ornamental frame on the cover, and even this decoration was not present on all of their works. ${ }^{35}$ The absence of surviving examples of fancy printing, however, does not mean that they never existed. Indeed, we have already noted that Chewett and Company were capable of producing fine lithographic and engraving work.

W.C. Chewett and Company's successful retail business inevitably led to a rapid rise in the value of the company itself. This is documented in the City of Toronto Tax Assessment Rolls. The assessment for I858, when the business was still officially known as Maclear and Company, stated that the total value of the personal property of the business was $\$$ I0,000. ${ }^{36}$ After George Thomas' departure, the value of the personal property dropped to $\$ 4,000$ in the assessment for $1859 .{ }^{37}$ The firm retained this $\$ 4,000$ total from 1859 to 1863 . By I864, however, the prosperity of the business had become evident, and the total value of the company's personal property was set at $\$ 10,000 .{ }^{38}$ Only four years later, in 1868 , the total reached $\$ 20,000 .{ }^{39}$ By 1868 the business had become so successful that the partners could afford to build an addition to their shop and to buy a new lithographic press. ${ }^{40}$

The financial stability and steady growth of W.C. Chewett and Company ensured a respectable credit rating. Beginning in 1864, The Mercantile Agency Reference Book ..., compiled by R.J. Dun and Company, listed credit ratings for the principal merchants in Canada. In the volumes for I864 to I869, Chewett and Company maintained a consistently high rating. In all of these years the company's 'general credit' was listed at level one, 'high.' This rating was at the second highest level, below the 'AI, unlimited credit' rating, but it was above the 'good credit' rating. More importantly, the company's credit rating was consistently higher than the ratings for all of the other major Toronto booksellers, printers, and publishers listed, including Brown Brothers, Rollo and Adam, and Henry Rowsell. ${ }^{41}$

A fairly large staff was required to operate such a successful and diverse 
business. The Toronto tax assessment rolls are useful in providing information about the staff of W.C. Chewett and Company (see Appendix Two). The tax rolls prior to I 863 gave only basic information about the major employees, and only four to six people were listed each year from I859 through I862. Beginning in 1863 , however, the assessment was much more detailed and listed a larger number of employees as well as each employee's age and position at the firm. Were the twenty-four persons listed in the 1863 assessment, the eighteen persons listed in the 1864 assessment, and so on, all the employees working at W.C. Chewett and Company at the time of assessment? We may conclude that even if the lists were not exhaustive, they certainly contained the majority of workers there, certainly those with taxable incomes.

These lists of employees are very interesting. They chronicle the growth of the business; for example, in I863 Chewett and Company had one clerk, while by 1866 they had enough business to employ three salesmen. The lists show that the company usually employed more printers than binders during the I86os, and that as the business grew, tradesmen with particular skills, such as ruling, were employed. By I867, Chewett and Company were able to take on an apprentice printer. ${ }^{42}$

There is considerable confusion about when W.C. Chewett left the firm of Chewett and Company. The Books and Notions article on W.W. Copp stated that Chewett retired in 1865 , 'and Mr. Copp and Mr. Clark formed the firm Copp, Clark \& Co.43 This is obviously an oversimplification of the facts. Unfortunately, in this instance the assessment rolls are of little help. Chewett was listed with the company until I868. In the entry for I865, brackets were placed around the names of Copp and Clark, excluding Chewett, perhaps meaning that Chewett was no longer an active partner in the firm. This notation was continued in I866, but in I 867 and I868 Chewett's name was included within the brackets, along with Copp and Clark. ${ }^{44}$ The Toronto city directories are also of no help in this matter, as they listed Chewett as a member of the firm until I $868 .^{45}$

Even if Chewett did retire in 1865 , the firm remained 'W.C. Chewett and Company' until r869, when Copp and Clark officially purchased control of the company and changed its name to Copp, Clark and Company. ${ }^{46}$ This move to control the firm and to buy out Chewett's interest placed quite a strain on the business, a fact that is documented in both the City of Toronto Tax Assessment Roll for 1869 and in the credit ratings listed in the I87I volume of The Mercantile Agency Reference Book... The assessment for 1868 listed twenty-eight employees at Chewett and Company, while that for 1869 listed only fourteen. ${ }^{47}$ The change in management had necessitated a cut in staff, which in turn may have made the firm less financially stable. In any case, in I87I The Mercantile Agency Reference Book ... cut the company's general credit rating from 'high' to 'good.'48 
William C. Chewett had left the printing and publishing trade by at least I869, but he was not inactive for long. By I872, he had joined the A. and S. Nordheimer Company, a firm that was at the time 'the leading house in the Dominion engaged in the publishing [of] music..... ${ }^{49}$ Coincidentally, Nordheimer and Company was located at I 5 King Street East, directly next door to Chewett's old firm.

It may seem strange that a man of Chewett's background should become the manager of a music publishing business. An examination of Chewett and Company's imprints suggests few musical leanings, although several lithographed sheet music covers were produced for the Nordheimer company. Chewett's competence in managing a publishing firm must, however, have been very familiar to Samuel Nordheimer, and this expertise was undoubtedly appreciated. Chewett's work at Nordheimer and Company was no doubt fairly demanding because of the company's size and reputation. Business Sketches, published about 1867 , stated that Nordheimer's first flat was '... devoted to sheet and book music of all kinds, embracing all the popular music of the day, both European and American,' and that 'hardly a day passes but some new piece of music is issued by this house. ${ }^{50}$ Chewett managed the Nordheimer firm from I872 until I880 or I88I; by September I88I he had been replaced by Adolph Peterson. ${ }^{51}$

What did William C. Chewett do during the few years between leaving Chewett and Company and joining Nordheimer's and in the sixteen years after leaving Nordheimer's until his death in 1897 ? Chewett was a man of many interests. In addition to his printing and publishing activities, he was also involved in an important hotel business. William Canniff, in The Medical Profession in Upper Canada, 1783-1850, stated that

In I832, Mr. [J.G.] Chewett erected in York a block of buildings at the corner of King and York Streets, in which was established a commodious hotel, known as the British Coffee House, kept by a Mr. Keating. The present Rossin House occupies the same spot. This valuable piece of land was patented to Isabella, wife of Col. Chewett, and Dr. W.C. Chewett is the present owner. ${ }^{52}$

The Rossin House Hotel, built in I 856, was one of the major hotels of Toronto for many years. It was patronized by many important people, and it accommodated the Prince of Wales (later Edward viI) during his visit to Toronto in I860. When the hotel was destroyed by fire in I864, many of Toronto's leading citizens, including Chewett, raised the necessary capital and formed a joint stock company to oversee the rebuilding of the Rossin House on an even more magnificent scale..$^{53}$

The Chewett family's involvement with the Rossin House did not necessarily mean that they were made very wealthy by it, a point that is demonstrated in William C. Chewett's will, dated Io January I894. It listed the value 
of his property at $\$ 59,716$, a considerable sum; but a closer examination reveals that $\$ 57,500$ of this was tied up in 250 shares of the Rossin House Hotel Company. ${ }^{54}$ This interesting fact may suggest one reason why W.C. Chewett worked for the Nordheimer company. Chewett may have been financially well-off, but not to the extent that he did not have to work. Since most of his wealth appears to have been tied up in the Rossin House Hotel Company, working for the Nordheimer company would have provided a dayto-day income.

There is no question that Chewett was closely involved with the Rossin House Hotel in the years before his death. In the Toronto city directories for the years I885, I886, and I890, his business address was listed as 'Rossin House.': Chewett's obituary in the Evening News on 3 December 1897 stated that 'he retained to his death his interest in the land upon which stands the Rossin House..$^{.56}$

When Chewett died on 30 November 1897, at the age of sixty-nine, he appears to have already fallen into obscurity. The major Toronto newspapers, including the Globe, the Daily Mail and Empire, and the Evening News, carried brief obituaries hidden away on back pages. ${ }^{7} \mathrm{He}$ was remembered as a member of a prominent Torontonian family and for his medical studies. None of the obituaries mentioned Chewett and Company or any involvement with the printing and publishing trade of Toronto! The trade journals Bookseller and Stationer and the Canadian Printer and Publisher both ignored Chewett's passing. By contrast, when Thomas Maclear, Chewett's old partner, died early in 1898 , he was given a prominent obituary in Bookseller and Stationer, and although Chewett was mentioned in the notice, nothing was said of his recent death. ${ }^{5}$ That Chewett by 1908 was largely forgotten is demonstrated by a reference in Robertson's Landmarks of Toronto, which stated:

Mr. J.G. Chewett was the father of the late Dr. J.G. [sic] Chewett, who at one time had the principal book establishment in Toronto...." ${ }^{\text {s) }}$

William Cameron Chewett helped to consolidate, improve, and expand an already well-established and important Canadian publishing business. The period during which the firm was under his guidance was an important link between the early businesses of Scobie and Maclear and Company and the later successes of the Copp, Clark Company Limited. As this firm remains an active concern, Chewett's contribution to Canadian publishing may be said to be still very much with us. 
NOTES

I. [William C. Chewett, comp.], Biographical Sketch of the Late Colonel Chewett (Toronto: C. Blackett Robinson, I890), I 8 pp. (An offprint of an article published in the Proceedings of the Association of Land Surveyors of Ontario (1890): IOI-I I6; Pamph., I890, No. 6I, Archives of Ontario, Toronto, Ontario); W. Stewart Wallace, The Macmillan Dictionary of Canadian Biography, $3 \mathrm{~d}$ ed., rev. and enl. (London: Macmillan, I963), p. I35.

2. Robertson's Landmarks of Toronto: A Collection of Historical Sketches ..., Published from the Toronto 'Evening Telegram,' 6 vols. (Toronto: J. Ross Robertson, I894-I9I4l, 5: 562.

3. William Canniff, The Medical Profession in Upper Canada, 1783-1850: An Historical Narrative, with Original Documents Relating to the Profession, Including Some Brief Biographies (Toronto: William Briggs, I894), p. 294; 'James Grant Chewett,' Dictionary of Canadian Biography, Volume IX, I86I to I870 (Toronto: University of Toronto Press, I976), pp. I28-129.

4. Canniff, p. 294

5. Fasti Academici: Annals of King's College, Toronto, 1827-1849 (Toronto: Henry Rowsell, i 850), pp. I6, 32-33.

6. W.J. Loudon and W.J. MacLean, comps. and eds., University of Toronto Fasti from 1850 to 1887 (Toronto: Williamson and Co., I 887), unpaged.

7. Canniff, p. 295.

8. Unfortunately Sinclair did not list the source of this information. See David Sinclair, 'The First Pirated Edition of Tennyson's Poems,' Book Collector 22 (I973): I84.

9. Elizabeth Hulse, A Dictionary of Toronto Printers, Publishers, Booksellers, and the Allied Trades, 1798-1900 (Toronto: Anson-Cartwright Editions, I982), p. I65.

Io. H. Pearson Gundy, Book Publishing and Publishers in Canada Before 1900 (Toronto: Bibliographical Society of Canada, 1965), p. 17.

II. Hulse, p. 58 .

I2. The exact dates of the assessment were given for some years, especially in the I870s, when they were always dated in September.

I3. City of Toronto Tax Assessment Roll for the Ward of St. Lawrence, I8 58, G S-6I4I, Archives of Ontario, Toronto, Ontario. (Assessment rolls hereafter cited as CTAR, followed by the year and Gs number.)

I4. 'Men of the Times: Mr. W.W. Copp,' Books and Notions 7 (July r89r): 6.

I5. Ibid.

I6. Hulse, p. I65.

I7. CTAR, I858, GS-6I4I.

I8. See the advertisement dated September I86I and signed 'W.C. Chewett \& Co., (Late Maclear \& Co.)' in Great Western Railway Gazetteer, Commercial Advertiser and Business Directory, 1861-1862, no. I (Toronto: J.L. Mitchell \& Co., publishers and compilers; printed by W.C. Chewett \& Co., I86I), p. 93.

I9. 'Men of the Times: Mr. W.W. Copp,' p. 6.

2O. CTAR, I859, GS-6I42.

2r. Hulse, p. 70.

22. 'Men of the Times: Mr. W.W. Copp,' p. 6.

23. CTAR, I 859 and I 860, GS-6I42 and GS-6I43.

24. CTAR, I86I, GS-6I44.

25. CTAR, I862, GS-6I45.

26. Great Western Railway Gazetteer, p. 93. 
27. Ibid.

28. W.C. CHewett e) Co.'s Illustrated Catalogue of Presentation Books for the Season, Iuvenile Books, Photographic Albums, etc., etc., Christmas 1865 (Toronto: W.C.

Chewett \& Co., I8651, 28 pp.

29. For prize lists of the Upper Canada Provincial Exhibitions, see the Journal of the Board of Arts and Manufactures for Upper Canada, vols. 2-7 (1862-1867). As the Exhibition was held in September, the lists appeared in the issues for October or November.

30. Hulse, p. 56.

31. 'Men of the Times: Mr. W.W. Copp,' p. 6.

32. See Sinclair, pp. 177-188.

33. See Frances M. Staton and Marie Tremaine, eds., A Bibliography of Canadiana; Being Items in the Public Library of Toronto, Canada, Relating to the Early History and Development of Canada (Toronto: The Public Library, 1934), no. 4497.

34. Sinclair, p. 184 .

35. Sinclair, p. 185 .

36. CTAR, I 858 , GS-6I4I.

37. CTAR, I859, GS-6I42.

38. CTAR, I864, GS-6I48.

39. CTAR, I 868 , GS-6I53.

40. W.C. Chewett $\Theta$ Co.'s Toronto City Directory, 1868-9 (Toronto: W.C. Chewett \& Co., I868), p. 167.

4I. The Mercantile Agency Reference Book for the British Provinces; Containing Ratings of the Principal Merchants, Traders, and Manufacturers in the Canada's, Nova Scotia, New Brunswick, Newfoundland, and Prince Edward Island, 8 vols. (Toronto: R.G. Dun and Co. [later Dun, Wiman \& Co.] I864-I869).

42. See CTAR, I859-I868, GS-6I42-6I53, especially I863 (Gs-6I47), I864 (GS-6I48), I 866 (Gs-6I50), and I867 (Gs-6I5I).

43. 'Men of the Times: Mr. W.W. Copp,' p. 6.

44. CTAR, I865-I868, Gs-6I49, 6I5I, 6I53.

45. See W.C. Chewett e) Co's Toronto City Directory, 1868-9.

46. 'The Copp Clark Company Limited Celebrate Centenary October First: I84I-r94I,' Bookseller and Stationer 57 (I5 September I94I): I5.

47. CTAR, I868, I869, GS-6I53, 6I55.

48. The Mercantile Agency Reference Book, II (I871): 475.

49. Business Sketches [Toronto: n.p., I867?], p. Ioo.

50. Ibid.

5I. CTAR, I872-I88I, GS-6I6I, 6I63, 6I65, 6I67, 6I7I, 6I73, 6I79, 6I83, 6I87, 6I88.

52. Canniff, p. 294.

53. 'The Rossin House, Toronto,' Canadian Illustrated News 3 (I3 May I87I): 295.

54. The Will of William Cameron Chewett, Surrogate Court, York Country, Toronto Wills I897-I898, no. I2404, GSI-1063, Archives of Ontario, Toronto, Ontario.

55. Toronto City Directory for $1885,[1886,1890]$ (Toronto: Compiled and published by R.L. Polk \& Co., I885, I886, I89o).

56. 'Deaths-Chewett,' Toronto Evening News, 3 December I897, p. 2.

57. 'Death of an Old Resident,' Toronto Globe, 2 December I897, p. I0; 'Deaths-Chewett,' Toronto Daily Mail and Empire, 2 December 1897, p. 5; 'Buried at St. James', Toronto Daily Mail and Empire, 3 December I897, p. 6.

58. 'Death of Mr. Maclear,' Bookseller and Stationer I4 (January I898): 2.

59. Robertson's Landmarks of Toronto, 5: 562. 
ADDITIONAL SOURCES CONSULTED

Anglo-American Magazine. Vols. I-5 (July I8 52 -December I8 54). Toronto.

Calderisi, Maria. Music Publishing in the Canadas, 1800-1867. Ottawa: National Library of Canada, I981.

Canadian Printer and Publisher. Vol. 6, no. I2-vol. 7, no. I (December 1897-January I898). Toronto.

Caverhill's Toronto City Directory, for 1859-60 ... By W.C.F. Caverhill. Toronto: Published by W.C.F. Caverhill; Lovell \& Gibson, printers, 1859 .

History of Toronto and County of York, Ontario; Containing ... Biographical Sketches, etc., etc. 2 vols. Toronto: C. Blackett Robinson, 1885.

Hutchinson's Toronto Directory, 1862-63 ... Compiled by Thomas Hutchinson. Toronto: Lovell \& Gibson, I862.

Mitchell and Co.'s General Directory for the City of Toronto, and Gazetteer of the Counties of York and Peel for 1866. Toronto: Mitchell \& Co., publishers; Lovell \& Gibson, printers, 1866.

University of Toronto Archives. Department of Graduate Records. File of William Cameron Chewett. A73-0026/057 (34).

All illustrations courtesy of the Metropolitan Toronto Library Board; except The Old Piney Woods, courtesy of the University of Toronto Library. 


\section{W. C. Chrgurtr \& Co.,}

DUBIISHERS OF TIE GREIT WESTERN AND GRAND TRUNK RAILWAY 1 DIRECTORILS, beg to inform their numerous readers that the business conducted for the past seven years unler the style of MACLEAR \& CO., will in future be known by the above name. In making this announcement they desire to give pro. minence to the fact that the cbange is one of name only ; the business is still conducted by those who, under the old name, succeeded in giving satisfaccion to so large a body of customers, and who are now prepared to lievote the utmost attention and energy to executing every order, large or small with which they may be honored. Their establishment and its capabilities are now so well known throughout Upper Canada, that it is unnecessary to remark at length on the various departments; they would, however, briefly indicate them, assuring their friends that every effort is made, and no expense spared, to seep each branch of their business up to the mark.

\section{BOOKSELLING.}

In this department will be found an assortment of STANDARD WORKS, ENGLISH and AMLRICAN, while every NEW WORK of IATEREST is added soon as published. Orders for miscellaneous Books from Europe sent weekly and executed more quickly than by any other establishment.

LAW BOOKS.-A full stock of ENGLISIf and AMERICAN EDITIONS kept on hand, which we offer at the lowest prices for Cash.

MEDICAL.-All the STANDARD TEXT BOOKS kept in stock, and supplied on very liberal terms to Students, and for Cash.

EDUCATIONAL. - We have always on sale the TEXT BOOKS used in the University, in Upper Canada College, the Model Grammar School, and all the principal Educational Institutions, public and private, in the Province.

\section{Bibles, Prayers, Church Services, Albums and Gift Books.}

A LARGE STOCK OF JUVENILE BOOKS.

The English and American Periodicals, Revieus, \&c., supplied immediately on paslication.

\section{STATIONERY.}

Our stock in this department comprises the best ENGLISH BOOK AND WRITING PAPERS. DE LARUE'S OVERLAND NOTE for Foreign Correspoadence, ENVELOPES, VISITING CARDS, \&c. These goods can cnly be obtained from two or three houses in the Province.

Our stock of ENVELOPES is at all times very large. Buff, from $\$ 1$ per 1,000 to the heaviest and finest made; also Cream Laid, Blue Laid, Cloth Lined, and every other description of Commercial or Official Envelopes.

GILLOTT'S and MITCHELL'S STEEL PENS. STEPHENS' ARNOLD'S, TODD'S, BLACKW

Every Article of Office Furnishing.

\section{PRINTING.}

AN EXTENSIVE PRINTING OFFICE, IN WHICH EVERY DESCRIPTION OF

BOOK ANT JOB PIRINTING

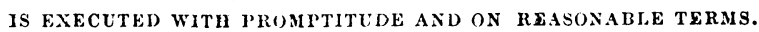

Printing for BANKS, INSURANCE and other Public Companies in very superior style.

AN MMENSE VARIETY OF

IEGAL, MCNICIPAI and COMMERCIAL PRINTED FORMS kept in Stock.

The Printing of SPECHA FOKMS, CATALOGUES, REPORTS, PAMPILETS, POLICILS, BILLS IN CHANCERY, Sc, expeditiously done, and with strict regard to economy.

W. C. CHEWETT \& CO., (late Maclear \& Co.,) 17 \& 19 King Strert List, Torovro, C.W.

An early advertisement for W.C. Chewett \& Co., 'late Maclear \& Co.'; from the Grand Trunk Railway Gazetteer ... 1862-63. 


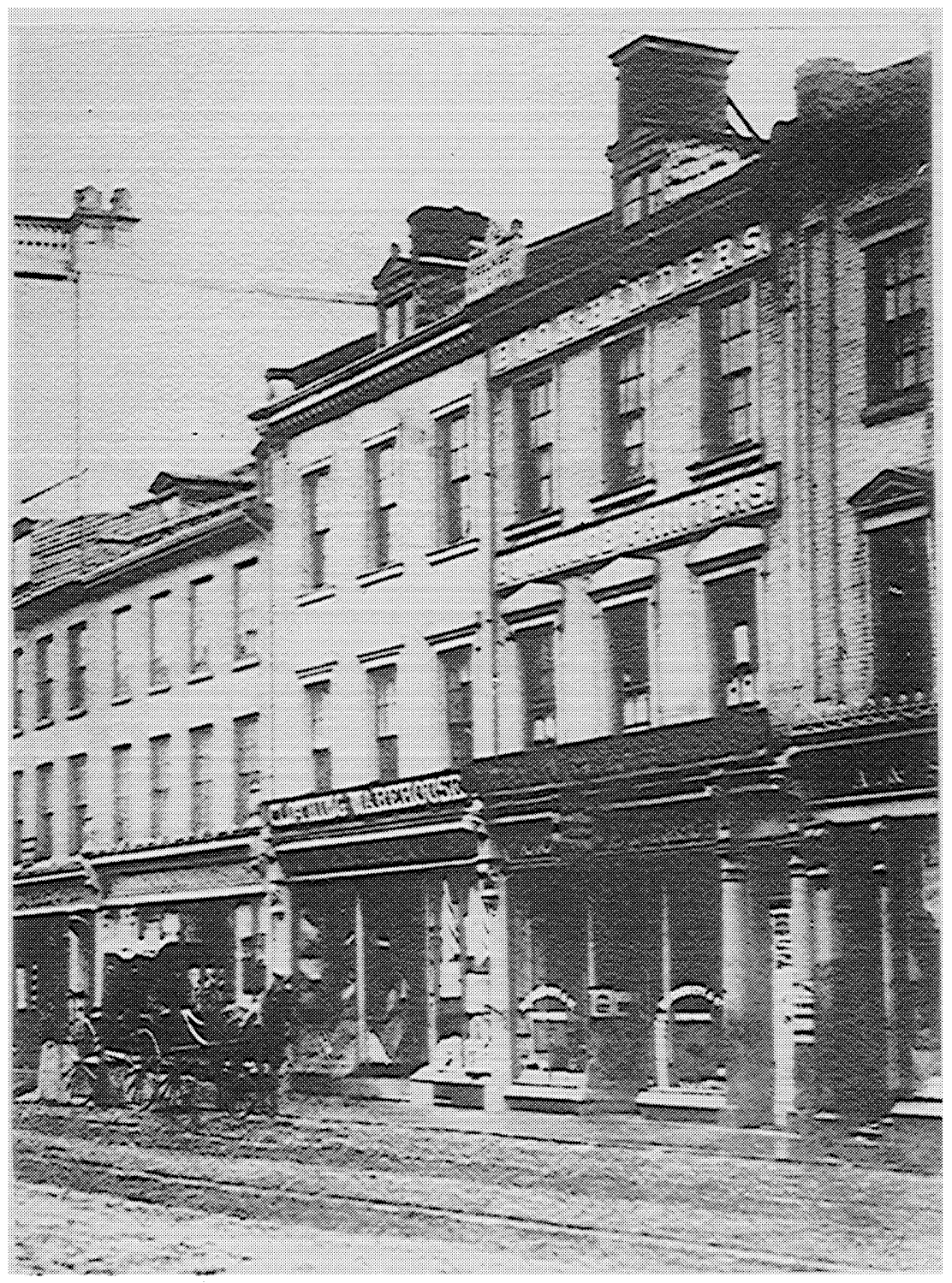

Chewett's shop on the south side of King Street East, Toronto, ca. I867. 


\section{W. C. CHEWETT \& CO.

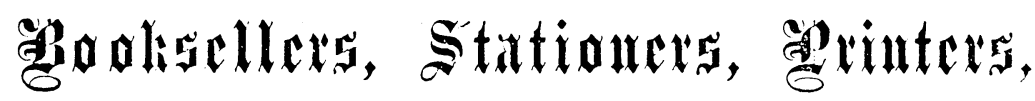
LITHOGRAPHERS, BOOKBINDERS, \&e. 17 \& 19 King Street East, Toronto.

PUBLISHERS OF THE

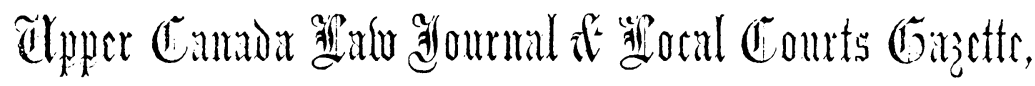
COMIMON PLEAS REPORTS,

\section{THE CANADIAN ALMANAC, \&C.}

EPPEL CANADA AGENTS FOR TIE SALE OF THE PROVINCIAL CONSOLIDATLD STATCTES, AND OTHER LEGISLATIVE ENACTIENTS.

\section{EDUCATIONAL BOOK ROOM OF UPPER CANADA, UNIVERSITY, COLLEGE \& SCHOOL BOOKS, LEGAL AND MEDICAL TEXT BOOKS,}

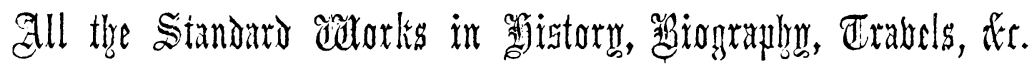
ENGIISH AND AMERICAN MAGAZINES AND REVIEWS.

The best $\mathrm{NEW}$ BOOKS are added as soon as published; any not in strock procured to order-from England in about six week, and from New York in one week. A large stock of

\section{FAMILY, PEW AND POCKET BIBLES \\ In every style and quality of Binding.}

Psalm and Hymn Books used by the various Denominations.

$$
\text { IPI IN TIING. }
$$

HOOK AND JOB PRINTING EXECUTED IN EVERY STYLE.

\section{IITIXOGIR A PIIT.}

Maps, Charts. Plans, Debentures, Bankers' Cheques, Promissory Notes, Drafts, Bill Heads, Business and Visiting Cards, \&c, engraved and printed in the first style, at the lowest prioes. A Stock of Labels for Druggists, Brewers, Grocers, \&c., kept on hand. Any style executed at short notice.

\section{EO OISIEXIN DIIT G}

Executed promptly, in a workmanlike and substantial manner. Large parcels of Books bound at very low rates.

\section{\&}

A full supply always on hand of the best English make of Writing and Book Papers, Enveloyes, Steel Pens, Stephen's, Morell's, Arnold's aud other Inks. Carmine and Scarlet Inks, together with every requisite for official or private use. Registry Books, Minute Books, Copying Books, Ledgers, Jouruals, Cash Books, kept ready, of the ordinary forms, or made to special pattern at short notice.

LEGAL, MLNICIPAL AND CONFEYANCING BLANK FOR.YS, de. (See List at end.) 


\section{PUI UII \\ W. C. CHEWETT \& CO. \\ LEGAL AND MUNICIPAL.}

A PRACTICAL TORK ON THE

OFFICE \& DUTIES OF CORONERS. ADAPTED TO THE CANADIAN LAW,

With a full Appendix of Forms and Schedule of Fees.

By WILLIAM BOYS, LL.B., Barrister-at-Law. Half Calf, $\$ 2$.

r B.-The portions of the work treating of Poisons, Post Mortem Examinations, and mat,ters connected with Chemical Analysis, have been prepared under the supervision of Professor Croft, of University College, Toronto.

$$
\rightarrow-
$$

IIANDY BOOK OF THE LAW OF DOWER; A with Statutes, Forins, Pleadings, \&c., couplete. By W. G. Draper, Lisq., Barristerat-Law. Half Calf, $\$ 3$.

WORKS BY R. A. HARRISON, EsQ. THE COMMON LAW PROCE CURE ACT OF 1856. The New Rules of Court, \&c., with Notes of all decided cases. Price, $\$ 8$, half calf. TIIE SUPERIOR COURT RULES, with Notes, Practical and Explanatory, $\$ 1$.

THE M AN U A L UF C OSTS IN COUNTY COURTS, with Forms of Taxed Bills in Superior Courts. 50 cents.

THE MUNICIPAL MAN UAL for Upper Canada, with Notes of Decided Cases. and a full Analytical Index. Price, $\$ 3$ cloth, $\$ 3.50$ calf.
A SYNOPTICAL INDEX OF THE

CONSOLIDATED STATUTES

of

CANADA AND UPPER CANADA,

With Notices of the more recent Statutes which affect them.By JoHN Webster IIAxCOCK, Hisq, LL.B., Barrister-at-Law, author of "A System of Conveyancing," etc. Half sheep, $\$ 5$.

$$
\longrightarrow
$$

RLACKSTONE'S C O M M EN TA RIES; by

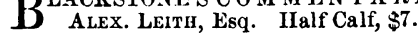

THE MAGISTRATES MANUAL, containing a Digest of the Criminal Law of Canada, with Forms, \&c., \&c.: By JoHN McNAB, E\&q., and Crown Attorney of York and Peel. Full sheep, $\$ 4$.

\section{ANNOUNCEMENTS.}

A IIANDY BOOK OF COMMERCIAL LAW FOR UPPER CANADA ; By ROBERT SULLIVAN, Esq., M.A., Barristar-at-Law. (Prepuring.) A TREATISE ON THE LAW AND PRACTICE IN EJECTMENT; By R. Snelling, Esq., LL.B., Barrister-at-Law. (Preparing.)

DIVISION COURT ACTS, RULES \& FORMS, WITII NOTES PRACIICAL \& EXPLANATORY. By Henry O'Brien, Esq., Barrister at Law. (Preparing.)

THE CONSTABLE'S GUIDE, by Hon. Judge Adam Wrison. \$1 00.

THE MUNICIPAL OFFICERS' READY RECKONER. \$1 00 .

\section{THE UPPER CANADA LAW JOURNAL,}

Edited by R. A. Ilarrison, Esq., W. B. ArdaGh, Esq., and H. O'Brien, Esq., Barristers at-Law.

Price $\$ 3$, paid in Advance.

THE LOCAL COURTS, GAZETTE,

Same Editors. Price $\$ 2$, paid in Advance. Both together, $\$ 4$, in Advance.

THE COMMON PLEAS REPORTS OF UPPER CANADA. Vøl. 15.-VAN KOUGHNET. $\$ 500$ in advance.

\section{MIISO OMIINAITHOUE.}

A POPULAR AND PRACTICAL EXPOSITION OF THE MINERALS AND GeOL,OGY OF CANADA. By E. Chapman, Ph.D. \$1 50.

THE GEOLOGY, OIL FIELDS AND MINERALS OF CANADA WEST. Illustrated with Two Maps. By Henry White, P.L.S. \$2 00.

OBESITY : The Various Causes, and the Rational means of Cure. From the French of Dancex. Translated hy M. Barretr. Cheap Edition. $25 \mathrm{cts}$. NAPOLEON III. ; THE MAN OF PROPHECY. By G. S. Faber. 40 cts.

Together with various Educational Works as contained in our Educational Catalogue.

\section{W. C. CHEWETT \& CO.}

$17 \& 19$ King Street East, Toronto. 


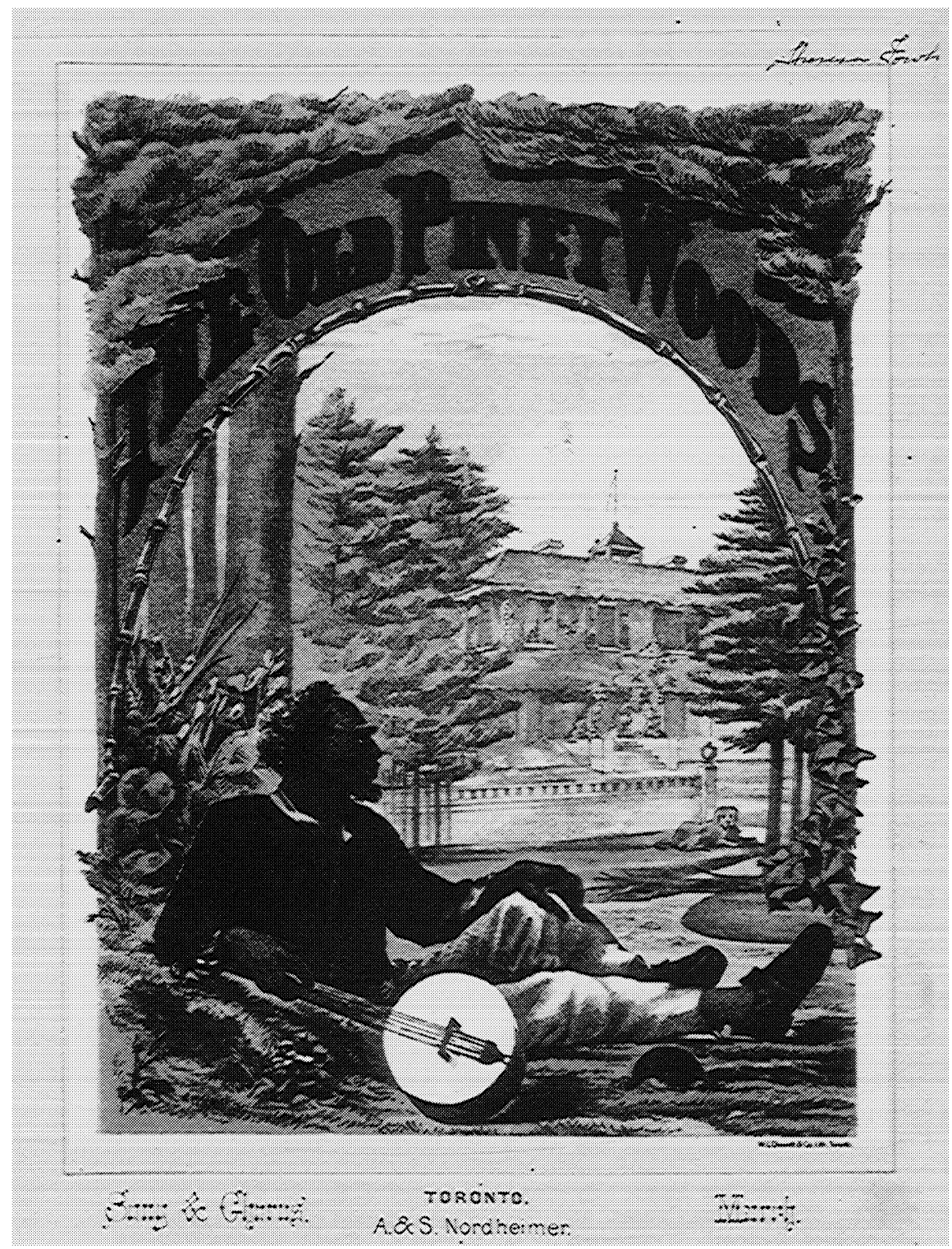

This sheet music cover (I866) is an example of outstanding lithographic work in colour produced by this firm. 


\section{BLANK FORMS.}

The following are selected from our General List of Blanks, with which the numbers prefixed correspond. In ordering, it will be sufficient to give the quattity and Number. Full Lists of our Blanks Free on Application.

\section{CONVEYANCING.}

1 Affidarits of Execution of Deed and Memorial ....................... 100,100 2 Agreements fir sale of Land ....... doz. 040 3 Apprenticeship Indentures ......." " 0 " 040

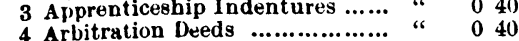
4 Arbitration Deeds ................. “

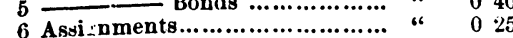

6 Assi.nments......................... " “ 025

7 - of Judgment............ “ 040

$8 \longrightarrow$ of Lerse ................. " " 040

$9=$ of Mortguge ............ " * 063

10 for Benəfit of Cred.. " “

11 Bills of Sale .......................... "

12 Bonds ................................. " * $\begin{array}{llll}0 & 25 \\ 13 & 0 & 25\end{array}$

13 — Money ......................... " " $\quad$\begin{tabular}{llll}
0 & 25 \\
\hline
\end{tabular}

15 - for Bal. of Purch. Money " “ 040

16 of Indemnity ............... * 040

17 Chattel Mortgage....................... " " 040

18 tor Future Advances ".... 040

19 Deeds with Bar of Dower, Full “ 080

20 Covenants w..................... “ “ 080

21 under Statutes .................... « 063

2.2 — withont Dower, ditto..... * * 063

2.3 Deeds of Part nership ............... " " 075

24 Discharge of Mortgage ............. « 4025

25 General Release of all Demands. " “ 025

26 Inventory ............................... " " 025

27 Leases, House ......................... *

$2 s$ - Land............................ " " 0040

29 —, Farm ................................. " " 040

30 _

31 _ with Power, Renewal \&

Purchase, \&c........................

32 Marine Protests ....................

33 Mortgages, with Bar of Dower...

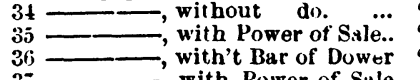

37 and Insurance Clause ..........

38 and Insurance Clause .........

39 Mort gage of Lease ....................

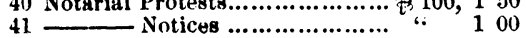

42 Notices to Quit............................ “ ، 100

43 Notice of Sale under Mortgage... Th doz. 025

44 Powers of Attorbey (blank) ...... " 040

$4 j$

Debts, \&c...................... “

46 Warrants of Distress .................. " " 0.25

47 Quit Clitim Deeds, wh B. of D'er “ “ 00 ti3

$4 \mathrm{~S} \longrightarrow$, without do... " " 063

\section{CORONERS' BLANKS.}

111.2 Recognizances

$\leqslant$ c.

110.3 Summons to Jurcrs.............. is 0 i.j

$11.4-$ to Wituess ............ " 6 . 0 .5

10.) Warrant to Constable ............. 6 6 075

$106 \mathrm{t}$ of Commitment .........

\section{MAGISTRATES' BLANKS.}

170. Convictions........................ क $100, \$ 150$

171 Deposition of Witnesses....... क doz. 025

172 Informations ..................... क 100,075

173 Notices of Appeal............... " " 150

174 - of Conviction ............ " " 0 \%

$175-$ of Recognizance ........ " " 075

176 Recognizance to Appear...... " " 100

177 - to keep the Peace. “

178 - to give Evidence. " " 150

$179-$ to Prosecute...... " " 150

180 Summons to Defendant ....... " $\quad 0 \quad 75$

181 Search Warrant.................. " " 075

182 Summons to Witness .......... " " 075

183 Warrunt to Arrest Defendant “ $\quad 150$

181 - of Commitment.... " " 150

$185=$ upon Conviction for

a Penalty........ “ 150

187 under Kemand

188 disobeyed ... " " 150

$189 \begin{array}{r}\text { viction for Penalty } \\ \hline\end{array}$

for the payment of money.

\section{MUNICIPAL.}

$\$$ c.

210 Assessment Rolls, Township.

211 - non-resident. " $0062 \frac{1}{8}$

212 - Towns... " "

$213-$ non-resident.... " " $\quad 062 \frac{1}{3}$

214 Notices-"Take "

215 Assessment Notices to leave for the party to fill in...... " " $037 \frac{1}{2}$

216 Assessment Notices, Towns, "Take notice that you are assessed"

217 Assessment Notices, Towns, Notices to leave," for the party to fill in................

218 Collector's Rolls, Township.

219 - Town.........

$220=$ Non.resd't..

221 Collector's Receipts.............

222 Voters Lists .....................

223 Jurors Lists. 1st, 2nd, 3rd, and tth Divisions ...........

225 Notices of appointment to Oflice ...........................

226 Auctioneers' Licens 's ........

2.27 Ale and Beer sellers Licenses

2:2 Tavern Keepers' Licenses...

2:29 IInwkers', Pedlers', and Pet. ty Chapmen's Licenses ...

230 Innkeepers' Licenses..........

231 Innkeepers' Bonds...

232 Municipal Officer's Bonds...

2;33 Declaration of Office.......... "

$23 t+2$ Qualificstion.

235 Instructions to Assessors, according to latest Acts, by R. A. Harrison, Esq ... each $\cup 12 \frac{1}{4}$

\section{W. C. CHEWETT \& Co.,}

17 of 19 Klng St. East, Toronto.

Examples of ephemeral material printed by Chewett \& Co.; from McNab's

Magistrate's Manual (1865). 

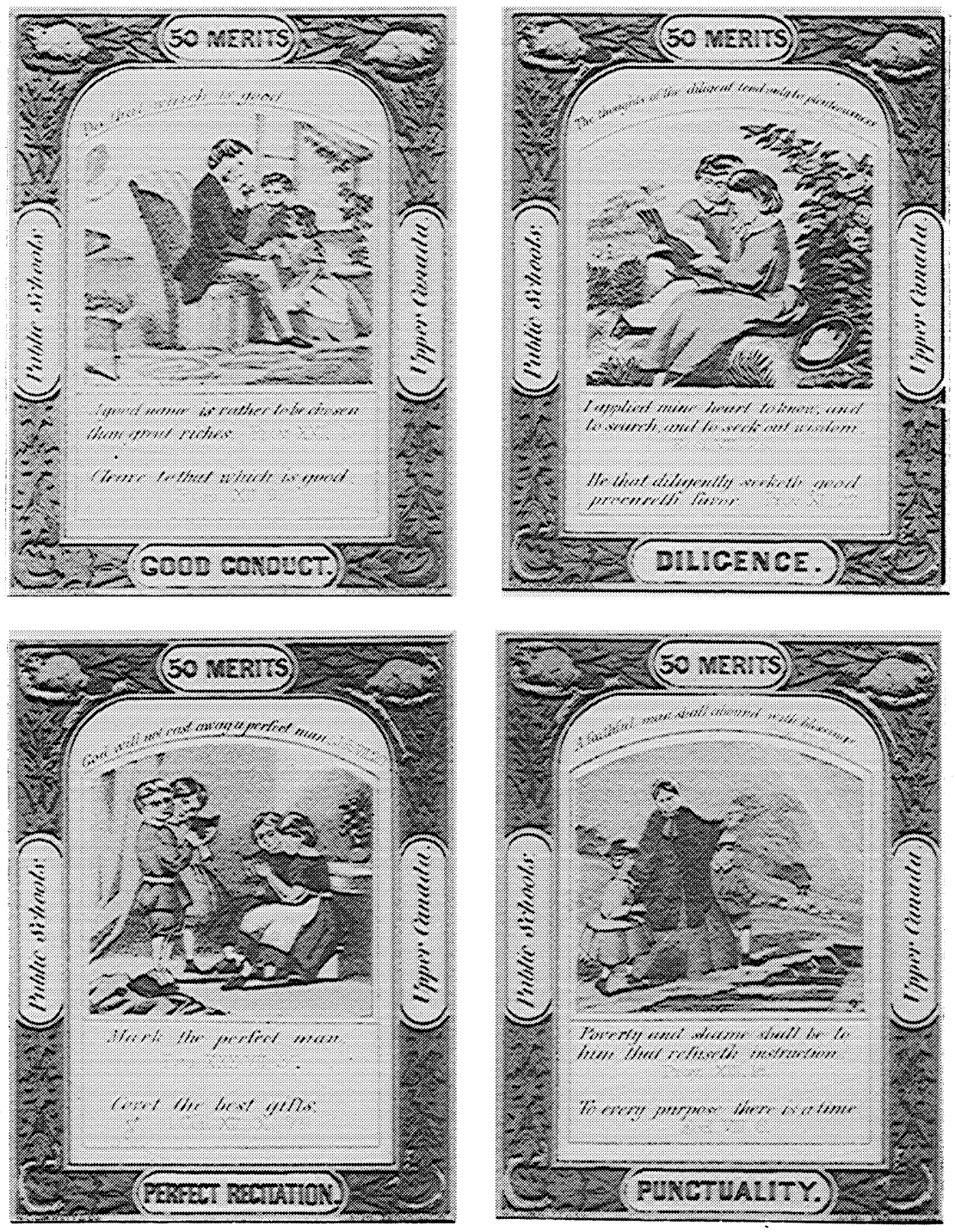

Four fine public school merit cards lithographed by W.C. Chewett \& Co. 


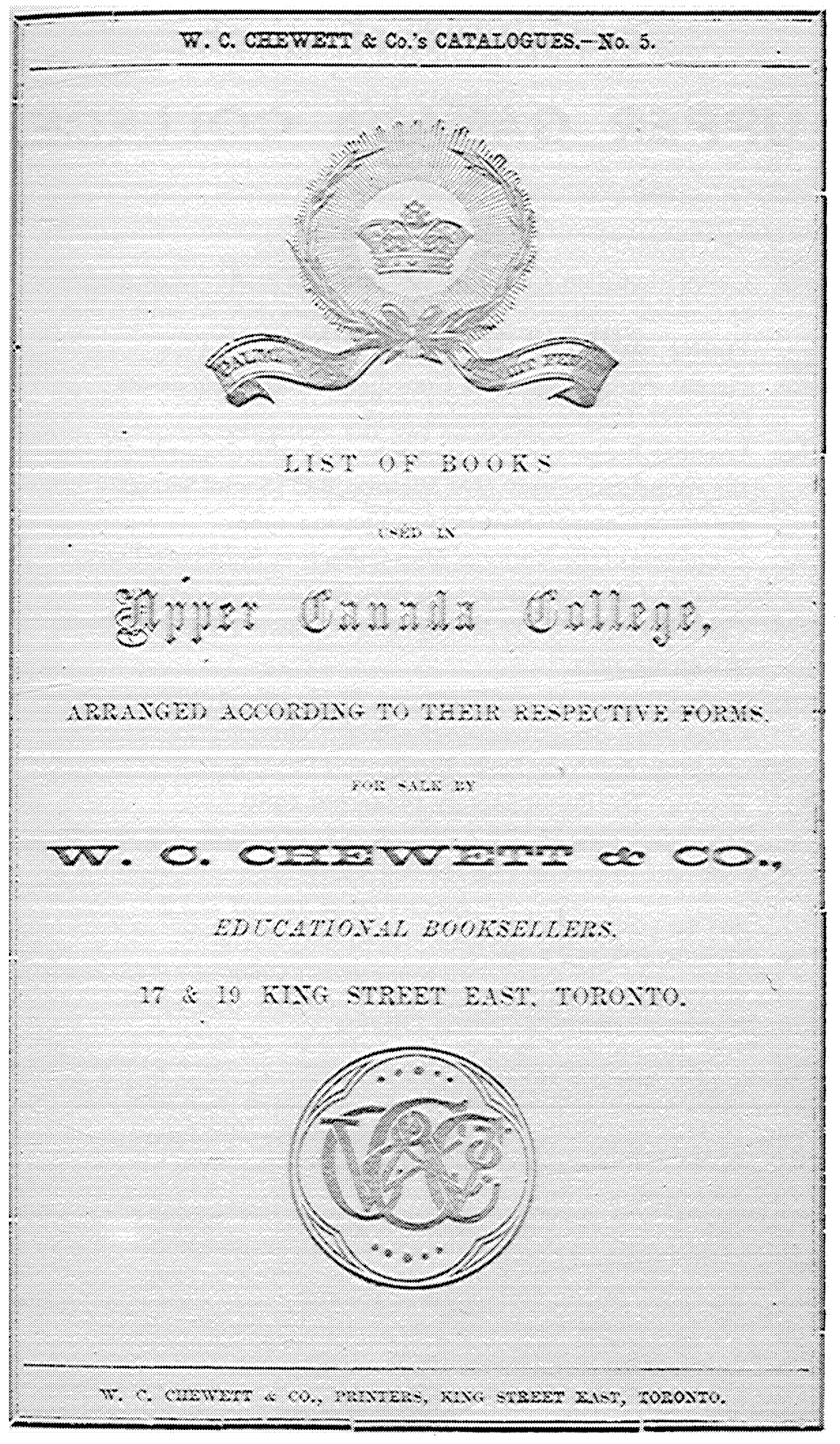

The cover of a company trade catalogue (I865). 


\section{Appendix One: A Chronological Checklist of W.C. Chewett and Company Imprints}

(Note: The list of copies located is not intended to be comprehensive. Imprints in Toronto libraries were examined wherever possible.)

BIBLIOGRAPHIES AND CATALOGUES CITED

Casey Casey, Magdalen. Catalogue of Pamphlets in the Public Archives of Canada, 1493-1877. With Index. Ottawa: F.A. Acland, King's Printer, I93I.

Haight Haight, Willet Ricketson. Canadian Catalogue of Books, 1791-1897. London: H. Pordes, I958.

Lowther Lowther, Barbara J. A Bibliography of British Columbia: Laying the Foundations, 1849-1899. Victoria, B.C.: Social Sciences Research Centre, University of Victoria, I968.

NMC Catalogue of the National Map Collection, Public Archives of Canada, Ottawa, Ontario. I6 vols. Boston: G.K. Hall, 1976.

Retro Canadiana, 1867-1900: Monographs. Ottawa: National Library of Canada, I982.

TPL Staton, Frances M. and Tremaine, Marie, eds. A Bibliography of Canadiana, Being Items in the Public Library of Toronto, Canada, Relating to the Early History and Development of Canada. Toronto: The Public Library, 1934; rptd. I965.

Boyle, Gertrude M., ed. A Bibliography of Canadiana, First Supplement... Toronto: The Public Library, 1959; rptd. I969.

KEY TO LOCATIONS

$\mathrm{OH}$ Hamilton Public Library

OKQ Queen's University, Kingston

OONL National Library of Canada, Ottawa

OOP Library of Parliament, Ottawa

OTAR Archives of Ontario, Toronto

OTER Ontario Institute for Studies in Education, Toronto

OTMC Massey College, University of Toronto

OTMCL Metropolitan Toronto Library

OTLS Law Society of Upper Canada, Toronto

OTREC Regis College, Toronto

OTUFM Faculty of Music, University of Toron to

OTURS Thomas Fisher Rare Book Library, University of Toronto

OTYL Law Library, York University, Toronto

QMBM Bibliothèque de la Ville de Montréal

SSU University of Saskatchewan, Saskatoon

Suddon Private collection of Alan Suddon, Toronto 
Section One: General Monographs

(Unless otherwise indicated, imprint reads: W.C. Chewett \& Co., printers.)

1861

Brown's Toronto General Directory, 1861 ... Comprising amongst Other Information, Street Directory, Commercial Directory, Trades Directory, City Directory, and Banking et Insurance Directory; With Miscellaneous, Detail, and General Information. Printed and published by W.C. Chewett \& Co. 395 pp. OTMCL OTURS

Great Western Railway Gazetteer, Commercial Advertiser and Business Directory, 1861-62. No. I. To be revised and continued. J.L. Mitchell \& Co., publishers and compilers. xiii, $397 \mathrm{pp}$. OT MCL

The Minutes of the Synod of the Presbyterian Church at its First Session in Montreal, C.E., June 6-13, 1861. Printed by Order of the Synod. 6o pp. OTMCL

Wilson, Adam, (Sir), I84I-I89r. The Constable's Guide: A Sketch of the Office of Constable. By Adam Wilson, Esq., Q.C. I50 pp. TPL 599 I OT MCL

1862

Canadian Bicentenary Papers. No. I. The History of Nonconformity in England in 1662. By Rev. W.F. Clarke. No II. The Reasons for Nonconformity in Canada in 1862. By Rev. F.H. Marling. 69 pp. TPL 4I2I OTMCL

Clarke, Rev. Wm. F., and Tucker, Rev. R.L. A Mother in Israel; Or, Some Memorials of the Late Mrs. M.A. Lyle. By her sons-in-law, Revds. Wm. F. Clarke and R.L. Tucker. I6 pp. OT MCL

Coulon, Emile. Nouvelle grammaire française; Comprising Vocabularies and Exercises, a Complete Grammar to the Syntax, etc., and a Reading Book. Par Emile Coulon. Second edition. Printed and published by W.C. Chewett $\&$ Co. xii, [9]-r9i pp. oturs

Crooks, Adam. Correspondence Arising out of the Pastoral Letter of the Right Reverend Francis Fulford, D.D., Lord Bishop of Montreal. 8 pp. OT UR S

'Essays and Reviews' Considered, by a Canadian Layman. 50 pp. TPL 4I37 OTMCL

Fleming, Sandford, (Sir), I 827-I91 5. Suggestions on the Inter-Colonial Railway, and the Construction of a Highway and Telegraph Line Between the Atlantic and Pacific Oceans, within British Territory. Respectfully submitted to the Government of Canada by Sandford Fleming. Toronto, August 5 th, I862. [77]-I34 pp. (An excerpt from H.Y. Hind's A Sketch of an Overland Route to British Columbia.) Low ther 65 (not seen)

Grand Trunk Railway Gazetteer, Commercial Advertiser, and Business Directory, 1862-63. No. I. To be revised and continued. J.L. Mitchell \& A.O. Loomis, publishers and compilers. ii-xvi, 639 pp. TPL 4I44 OTMCL 
Hind, Henry Youle, 1823-1908. A Sketch of an Overland Route to British Columbia. I2 8 pp. Low ther I7I (not seen)

[Lysons, Daniel, (Sir), I8I6-I898] Drill and Rifle Instruction for the Corps of Rifle Volunteers. By Authority of the Secretary of State for War. Tenth edition. W.C. Chewett \& Co., army printers. 73 pp. TPL 6OI5 OTMCL

Minutes of the Ninth Annual Meeting of the Congregational Union of Canada, Held at Hamilton, C.W., 11th-16th June, 1862; With Statistical Report. 23 pp. OTURS (t.p. dated I863; cover dated I862)

The Minutes of the Second Session of the Synod of the Canada Presbyterian Church Held in Toronto, June 3-12, 1862. Printed by Order of the Synod. 56, [liii] pp. OTMCL

[Tennyson, Alfred] Poems, MDCCCXXX. MDCCCXXXIII. Privately printed [by W.C. Chewett \& Co.] viii, II2 pp. OTMCL OTURS

1863

Burgess, James. The Present and Past Position and Future Destiny of the World, as Set Forth in Prophecy. By James Burgess. 24 pp. OT MCL

[Clarke, William Fletcher, I824-I902] 'In Memoriam': The Late Rev. John Roaf. I 2 pp. TPL 4232 OTMCL

[Dixon, Benjamin Homer, I8I9-I899? comp. Selected Hymns. ] I 5 pp. TPL 605I OTMCL OTURs (see also Sinclair, p. I85)

Draper, W.G. A Handy-Book of the Law of Dower; With Statutes, Forms, Pleadings, etc. By W.G. Draper, Barrister-at-law. Printed and published by W.C. Chewett \& Co. xxiii, I39 pp. OT Ls

Eclectic Female Institute, Brampton, C.W., Established Sept. 1, 1861, Henry H. Hutton, A.M., Principal. I5 pp. TPL 4209 OT MCL

Hallowell, J.S. Digest of Acts Passed during Sessions of 1860-1-2, which Repeal, Amend, Vary or Affect Consolidated Statutes for Upper Canada and Consolidated Statutes of Canada. By J.S. Hallowell, Student-at-law. 2o pp. OTMCL

Minutes of the Third Session of the Synod of the Canada Presbyterian Church Held in Hamilton, June 2-12,1863. Printed by Order of Synod. 64, lvi pp. TPL 4228 OTMCL

Narrative of the Dispute between the Bishop of Ontario and the Congregation of St. George's, Kingston, Relative to the Appointment of Dr. Lauder. 32 pp. TPL 4262 OTMCL

[Roche, Alfred R.] New Disposal of Convicts. Reprinted from the Letter of the Canada Correspondent of the London Moming Post, April 3rd, I856. 29 pp. TPL 3686 OTMCL

1864

Blackstone, William, (Sir), I723-I780. Commentaries on the Laws of England; Applicable to Real Property. By Sir William Blackstone. Adapted to the 
present state of the law in Upper Canada, by Alexander Leith, of Osgoode Hall, Barrister-at-law. viii, 4I6 pp. TPL 4284 OT MCL

Boys, William Fuller Alves. A Practical Treatise on the Office and Duties of Coroners in Upper Canada; With an Appendix of Forms. By William Fuller Alves Boys, LL.B., of Osgoode Hall, Barrister-at-law. W.C. Chewett \& Co., law publishers. xii, $295 \mathrm{pp}$. OTMCL OTURS

Chapman, Edward John, I82I-I904. A Popular and Practical Exposition of the Minerals and Geology of Canada. By E.J. Chapman, PH.D. With over two hundred woodcuts, and a copious index. W.C. Chewett and Co.; printed by Lovell \& Gibson, Yonge Street. xii, 236 pp. TPL 4304 OTMCL OTURS

Dancel, Jean François, b. I804. Obesity, or Excessive Corpulence: The Various Causes and the Rational Means of Cure. From the French of Dancel.

Translated and edited by M. Barrett.... xiv, I27 pp. TPL 6093 OTMCL /paper wrapper with imprint: Toronto: Copp, Clark \& Co., Front Street East, I873)

[Kirkwood, A.] Flax and Hemp. [1864?] 79 pp. Casey 3193 OTAR

The Mechanics' and Labourers' Almanack, 1864, and 'The Crookshank Estate' Advertizer. 43 pp. TPL 4339 OTMCL

Mitchell «) Co's County of Carleton and Ottawa City Directory for 1864-5. xx, $3 \mathrm{I} 4 \mathrm{pp}$. OTMCL

Mitchell's Toronto Directory, for 1864-5; Containing an Alphabetical Directory of the Citizens, a Street Directory, a Business Directory, or Classified List of Business, Trades and Professions, and an Appendix of Much Useful Information. 398 pp. OTMCL

Results of Meteorological Observations Made at the Magnetical Observatory, Toronto, Canada West, during the Years 1860, 1861, ↔) 1862. xxiv, 84 pp. TPL 4I88 OTMC OTMCL

1865

[Dixon, Benjamin Homer, I8I9-I899? comp.] Golden Moments... B.H.D. I 52 pp. TPL 6I5O OTMCL

Hancock, John Webster. A Synoptical Index of the Consolidated Statutes of Canada and Upper Canada; With Notices of the Later Acts which Affect Them; Including the Session of 1864. By John Webster Hancock, LL. B., Barrister at law, Berlin, C.W. Published by W.C. Chewett \& Co. and for sale by Rollo \& Adam, and all booksellers. 479 pp. TPL 4300 OTMCL (on verso of t.p.: John Lovell, printer, St. Nicholas Street, Montreal)

McNab, John. The Magistrate's Manual; Being a Compilation of the Law Relating to the Duties of Justices of the Peace in Upper Canada; With a Complete Set of Forms and a Copious Index. By John McNab, Barrister-at-law, etc. W.C. Chewett \& Co., publishers. viii, 658 pp. TPL 6I68 OTMCL

Scadding, Henry, r813-I901. Early Notices of Toronto. By the Rev. Dr. Scadding. 
26 pp. TPL 6I85 OTMCL

White, Henry. Geology, Oil Fields, and Minerals, of Canada West: How and Where to Find Them; With a New Theory for the Production and Probable Future Supply of Petroleum; Accompanied by Illustrated Geological Maps of Canada West and of the Oil Regions.... By Henry White, P.L. Surveyor, Toronto. IO9 pp. TPL 446I OTMC OTMCL

1866

Association of Canadian Lake Underwriters. 1866 Lake Vessel Register.

(Private property of the Association.) To be kept strictly confidential, and returned to the Office of the Association, at Toronto, when called for. 2511. TPL 6I95 OTMCL

The Fenian Raid at Fort Erie, June the First and Second, 1866; With a Map of the Niagara Peninsula, Shewing the Route of the Troops, and a Plan of the Lime Ridge Battle Ground. 95 pp. TPL 4497 OT MCL OTURS

[Patteson, Thomas Charles, I836-1907] Croquêt: The Toronto Laws... 20 pp. TPL 4529 OTMCL

Sullivan, Robert, I837-1870, and Moss, Charles. A Handy Book of Commercial Law, for Upper Canada. By Robert Sullivan, M. A., Barrister-at-law, mercantile law lecturer in Day's Commercial College, Toronto, and Charles Moss, Student-at-law. W.C. Chewett \& Co., publishers. $270 \mathrm{pp}$. TPL 4539 OTMCL OTURS

Wood, Samuel George. The Registry Act of 1865: 'Registration of Titles (Upper Canada) Act,' 29 Vic., Chap. XXIV.; With Notes of the Decisions of the Courts of Upper Canada, and a Selection of Those in the English and Irish Courts, on the Laws of the Registration of Deeds. By Samuel George Wood, LL.B., of Osgoode Hall, Barrister-at-law. 80 pp. OTUR S

1867

Bridgewater, Captain. Seven Years Military Life in Southern India: A Lecture Delivered in Canada West in 1867, by Captain Bridgewater, C.A.F., Comg. Mooretown, M.I., Late of H.M.'s 15th Hussars; Being an Interesting Narrative of a Soldier's Life in the Far East -Amusing Anecdotes - Castes and Ceremonies of the Natives - Indian Mutiny - An Hour at St. Helena, etc. etc.; Together with a Few Concluding Remarks to the Volunteers of Canada. W.C. Chewett \& Co., publishers. 24 pp. Retro OT MCL

The Canada Herd Book; Containing the Pedigrees of Improved Short-Horned Cattle. Volume first. Compiled by the Secretary, and revised by a Committee of the Board of Agriculture of Upper Canada. xliv, 5 Io pp. TPL 4557 OTMCL (not seen)

[Clark, Henry James, ca. I822-1892] The Gem: A Selection of the Most Popular and Choice Hymns and Tunes for Sabbath Schools. [Compiled by Henry J. 
Clark] I6o pp. Retro (no location given; not seen)

Douglas, James S., I80I-1878. The Reign of Peace, Commonly Called the

Millenium [sic]: An Exposition of the Nineteenth and Twentieth Chapters

of the Book of Revelation; In which it is Shown that the Millenium [sic]

There Spoken of is to be a Reign of Peace on Earth; Not the End, but the Summertime of the World, before the Coming of Christ to Judgment, and the Final Restitution of All Things. By the Rev. James S. Douglas, A.M., M.D., Missionary Minister of the Church of Scotland. 320 pp. Retro TPL 6258 OTMCL

The Fifth Book of Reading Lessons. Authorized by the Council of Public Instruction for Ontario. Canadian Series of School Books. [ca. I867] 534 pp. OTER

Harkness, Albert, 1822-1907. First Greek Book; Comprising an Outline of the Forms and Inflections of the Language, a Complete Analytical Syntax, and an Introductory Greek Reader; With Notes and Vocabulary. By Albert Harkness, PH.D., Professor of Greek in Brown University. The 'Au thorized Text Book' Series. xii, 276 pp. Retro oT MCL

Harkness, Albert, 1822-1907. An Introductory Latin Book, Intended as an Elementary Drill-Book, on the Inflections and Principles of the Language, and as an Introduction to the Author's Grammer, Reader, and Latin Composition. By Albert Harkness. ix, I62 pp. Retro оH OKQ (not seen)

Harkness, Albert, 1822-1907. A Latin Reader, Intended as a Companion to the Author's Latin Grammar; With References, Suggestions, Notes, and Vocabulary. By Albert Harkness. viii, 2I 2 pp. Retro oH OONL OTER (not seen)

Harrison, Robert Alexander, 1833-1878. The Municipal Manual for Upper Canada; Containing the New Municipal and Assessment Acts; With Notes of all Decided Cases, Some Additional Statutes, and a Full Index. By Robert A. Harrison, Esq. D.C.L., Barrister-at-law. Second edition. xxi, [17]-692 pp. TPL 4587 OTMCL OTURS

The Medical Register for Upper Canada, 1867. Printed and published under the direction of the General Council of Medical Education and Registration of Upper Canada.... 56 pp. TPL 46I2 OTAR

Rordans, Joshua Long, I824-1888. The Canadian Conveyancer and Hand-Book of Legal Forms; Being a Selection of Concise Precedents in Conveyancing, Carefully Revised, and Adapted to the New Registry Act; With Introduction and Notes; Forming a Compendium of Legal Instruments for the Lawyer, Justice of the Peace, Country Conveyancer, etc. By J. Rordans. Second edition. Printed by W.C. Chewett \& Co., for the proprietor, J. Rordans. 384 pp. Retro OTMCL

Sutherland, James, comp. City of Toronto Diretcory [sic] for 1867-8; Containing an Alphabetical Directory of the Citizens, a Business Directory, or 
Classified List of Trades and Professions, a Descriptive Sketch of the Principal Manufacturing Establishments, and an Appendix of Much Useful Information. James Sutherland, compiler. W.C. Chewett \& Co., publishers. $466 \mathrm{pp}$. OTMCL

1868

Astray. Printed in aid of the Drummondville Parsonage Building Fund. [1868?] 8 pp. Retro OTURS

Bovell, James, I8I7-I880. The World at the Advent of the Lord Jesus. By James Bovell, M.D., Lay Secretary to the Synod of the Anglican Church in Canada. 4I2 pp. OTURS

[Clark, Henry James, ca. I822-I892] The Gem: A Selection of the Most Popular and Choice Hymns and Tunes for Sabbath Schools. [Compiled by Henry J. Clark. 2d ed.] I6o pp. Retro OONL OTUFM

Harkness, Albert, I822-1907. A Latin Grammair for Schools and Colleges. By Albert Harkness. The 'Authorized Text Book' Series. xii, 355 pp. Retro OTLS

McKillican, John. Report of the Rev. J. McKillican, Missionary of the Sabbath School Association of Canada; Containing his Account of Sabbath Schools Organized and Visited in the Counties of Simcoe, Grey, and Bruce, in the Latter Part of the Year 1867. Published by Order of the ex-Committee. 14 pp. OTURS

MacMullen, John Mercier, I820-I907. The History of Canada, from its First Discovery to the Present Time. By John MacMullen. Brockville: Published by McMullen \& Co.; for sale by Dawson Bros., Montreal; Chewett \& Co., Toronto; and Sampson Low, Son \& Marston, London. xxxi, 6r 3 pp. TPL 3588 OTMCL

MacMullen, John Mercier, I820-I907. The History of Canada.... Second edition, revised and improved. xxxi, 6I 3 pp. TPL 3587 OTMCL

Scadding, Henry, I8I 5-I90I. The First Bishop of Toronto: A Review and $a$ Study. By Henry Scadding, D.D. 85 pp. Retro otar

The Spelling Book: A Companion to the Readers. [I868] Retro oonL [no paging given; not seen)

Toronto in the Camera: A Series of Photographic Views of the Principal Buildings in the City of Toronto. O. Thompson, photographic publisher, King Street West. 48 1l. OT MCL OTURS

W.C. Chewett 4 Co.'s Toronto City Directory, 1868-9; Containing amongst Other Information, a Street Directory, Alphabetical Directory, Business and Professional Directory; With a Very Full Appendix of Governmental, Legal, Corporation, Religious, Educational, and Other Valuable Local Information; Accompanied by a Map of the City. 455 pp. OT URs 
1869

The Assessor's Guide for Making the Assessments of Property in the Municipalities of the Province of Ontario (According to the Assessment Act of 1869). r8 pp. Retro oop (not seen)

Huron and Ontario Ship Canal Company. Summary Report on the Huron and Ontario Ship Canal. By the Huron and Ontario Ship Canal Company. 2d ed. $32 \mathrm{pp}$. Retro OKQ Q MBM Ssu (not seen)

McCaul, John, I807-1886. Christian Epitaphs of the First Six Centuries. By John McCaul. Published by W.C. Chewett \& Co. xxviii, 72 pp. OONL OTMCL OTREC

McMurray, William, I8Io-I894. Journal of a Mission to England, in the Year 1864, on Behalf of the University of Trinity College, Toronto. By the Rev. W. McMurray, D.D., Rector of Niagara, and Rural Dean. Printed for the University, by W.C. Chewett \& Co. 67 pp. Retro TPL 4337 OTAR

O'Brien, Henry, I836-193I. The Division Courts Act of 1869, and the Rules and Forms Promulgated by the Board of County Judges, on 9th April, 1869; With Explanatory Notes. Compiled by Henry O'Brien. [275]-48I pp. Retro OTU OTY L (not seen)

Point au Pelee Island, in Lake Erie, Now the Township of Pelee, in Essex, Ontario; Patented to the Members of the McCormick Family, in 1867; Incorporated as an Independent Municipality in 1868; The Lands on which are now Offered to the Public, for Sale, at Cheap Rates and on Easy Terms of Payment.... I4 pp. OTurs

DATE UNCERTAIN

(The following titles were advertised as Chewett publications in John McNab, The Magistrate's Manual (r865); no copies have been located.)

Faber, G.S. Napoleon III: The Man of Prophecy.

Harrison, Robert Alexander, I833-I878. The Common Law Procedure Act of 1856: The New Rules of Court, etc.; With Notes of all Decided Cases.

Harrison, Robert Alexander, I833-1878. The Manual of Costs in County Courts, with Forms of Taxed Bills in Superior Courts.

Harrison, Robert Alexander, I833-I878. The Superior Court Rules, with Notes, Practical and Explanatory.

The Municipal Officers' Ready Reckoner.

Snelling, R. A Treatise on the Law and Practice in Ejectment. By R. Snelling, Esq., LL.B., Barrister-at-law. (Preparing) 
Section Two: Serial Publications (arranged alphabetically)

Canada Permanent Building and Savings Society. Report of the Directors of the Canada Permanent Building and Savings Society, for the Year 1861[-68] W.C. Chewett \& Co., printers. OTMCL

The Canadian Almanac and Repository of Useful Knowledge for the Year 1862[-69]; Containing Full and Authentic Commercial, Statistical, Astronomical, Departmental, Ecclesiastical, Educational, Financial, and General Information. Printed and published by W.C. Chewett \& Co. OTMCL OTURS

The Canadian Independent. Vol. I2 (July I865-June I866). Published by the proprietors; W.C. Chewett \& Co., printers. OTMCL

—.Vols. I4-I5 (July I867-June I869). [Published by] Alexander Christie, for 'The Canadian Independent Publishing Company'; [printed by Chewett \& Co.] OTMCL (Chewett \& Co. probably printed this monthly serial for the entire period I862-I869; see Hulse, p. 56.)

The Index: A Commercial and Literary Monthly Journal, Representing Bryant, Stratton «) Odell's Business College. New ser., vol. I, no. I (September I866). OTMCL (No imprint statement; but possibly printed by Chewett \& Co., the only advertisers in the journal.)

The Iournal of the Board of Arts and Manufactures for Upper Canada. Vols. I-8 (I86I-I868). Edited by Henry Youle Hind, Esq., M.A., F.R.G.S. Printed for the Board of Arts and Manufactures for Upper Canada by W.C. Chewett \& Co. Oturs

The Local Courts' and Municipal Gazette. Vols. I-4 (1865-I868). Edited by W.D. Ardagh, Esq., Robt. A. Harrison, Esq., B.C.L., \& Henry O’Brien, Esq., Barristers-at-law. Printed and published by W.C. Chewett \& Co. ot LS The Municipal Reports; Containing Reports of Cases Arising under the Municipal and School Laws of Upper Canada. Vol. I (I863). Edited by Robert A. Harrison, Esq., B.C.L., and Thomas Hodgins, Esq., M.A., LL.B., Barristers-at-law. Printed and published by W.C. Chewett \& Co. OT LS

The Orphans' Home and Female Aid Society, Toronto. Thirteenth [-Seventeenth] Annual Report.... I864[-I868] W.C. Chewett \& Co., printers. TPL 5558 OTMCL

Reports of Cases Decided in the Court of Common Pleas, of Upper Canada. Vol. I4 (I863): From Michaelmas Term, 27 Victoria, to Trinity Term, 28 Victoria. By Edward C. Jones, Esquire, Barrister-at-law. W.C. Chewett \& Co., publishers. ot Ls

- Vol. I 5 (1865): From Michaelmas Term, 28 Vic., to Trinity Term, 29 Vic. By S.J. Van Kougnet, M.A., Barrister-at-law, and Reporter to the Court. W.C. Chewett \& Co., publishers. OTLS

- Vol. I6 (I866): From Trinity Term to Easter Term, 29 Vic. By S.J. Van Kougnet, M. A., Barrister-at-law, and Reporter to the Court. W.C. Chewett 
\& Co., publishers. ot Ls

The Upper Canada Law Journal and Municipal and Local Courts' Gazette.

Vols. 7-IO (I86I-I864).Edited by W.D. Ardagh, Esq., and Robert A. Harrison,

Esq., B.C.L., Barristers-at-law. Printed and published by W.C. Chewett \&

Co. OTLS

Upper Canada Law Journal (New Series). Vols. I-4 (1865-I868). Edited by W.D.

Ardagh, Robt. A. Harrison, \& Henry O'Brien, Barristers-at-law. Printed and published by W.C. Chewett \& Co. OTLS

\section{Section Three: Maps}

(Unless otherwise indicated, imprint reads: W.C. Chewett \& Co., lith.)

1861

Map of the County of Wellington, Canada West. Published by Guy Leslie and Charles J. Wheelock. Orangeville, I86I. NMC HI /42O-Wellington-I86I OTURS

Map of the District of Gaspé and Part of the County of Rimouski. Compiled by

E.E. Taché and A.L. Russell. NMC S/306-I86I; vi/306-I86I (not seen)

1862

Map of British North America, Comprising Upper and Lower Canada, Nova Scotia, New Brunswick, British Columbia, and the Islands of Prince Edward, Newfoundland and Vancouver. Prepared under the Supervision of the Educational Department for the use of the Public Schools of Upper Canada. NMC R/IIOO-[I862]; VI/IIOO-[I862] (not seen)

Map of Part of Canada West, Engraved Expressly for the Canadian Almanac, 1862. Published by W.C. Chewett \& Co. OTAR

Map of the Country from Lake Superior to the Pacific Ocean Showing the Fertile Belt Stretching from the Lake of the Woods to the Rocky Mountains and the Best Known Routes to the Gold Region of British Columbia. NMC H3/I IOO-I862 (from Henry Youle Hind, $A$ Sketch of an Overland Route to British Columbia, Chewett, 1862; not seen)

Map of the County of Renfrew. Compiled from authentic maps and documents by Andrew Bell, Civil Eng. \& Surveyor, Douglas, Sept. I862. $\mathrm{NMC} \mathrm{H} 3 / 42 \mathrm{O}-\mathrm{Renfrew}-\mathrm{I} 862$ (not seen)

New Map of the County of Huron Canada West. Compiled and drawn from original plans and actual survey by R.W. Hermon. Published by R.W. Hermon, R. Martin, and L. Bolton. NMC VR/42O-Huron-I862; VI/ 420-Huron/I862 (not seen)

Part of the North Shore of Lake Huron, Shewing the New Townships Subdivided into Farm Lots. Compiled \& drawn under the direction of 
Thomas Devine, Head of Surveys, U.C. Department of Crown Lands, Quebec, January I862. Engraved by W.C. Chewett \& Co. NMC H2/ 409-Algoma-I862 (not seen)

\section{3}

Chart of Lake Ontario. Compiled from surveys made by Capt. Owen \& Lieut. Herbert, R.N., and Capt. A. Ford, U.S.N., with the harbours and ports of the Lake. Surveyed by Edward M. Hodder, M.D., Commodore of the Royal Canadian Yacht Club. Lithographed, printed \& published by W.C. Chewett \& Co. NMC vi/4Io-Ontario-I863 (not seen)

Map of Part of Canada West, Engraved Expressly for the Canadian Almanac, 1863. Published by W.C. Chewett \& Co. NMC H3/40O-I863 (not seen) Plan of Part of the North Shore of Lake Huron, Shewing the Subdivisions of the New Townships. Department of Crown Lands. The Honble. Wm.

McDougall, Commissioner. NMC H2/409-Algoma-I863 (not seen)

1864

Park and Villa Lots on the Mackay Estate at Ottawa. NMC HI2/ 440-Ottawa-I864 (not seen)

Topographical Map of the Mackay Estate, Shewing the Divisions into Park, Villa, and Village Lots, and the Position of the Same with Relation to the City of Ottawa. Thos. C. Keefer, C.E. \& P.L.S. NMC vi/44O-Ottawa-I864

1865

Map of Canada West, Engraved and Published in the Canadian Almanack for 1865 by W.C. Chewett et) Co. OTAR

1866

Chart of Lake Ontario. Compiled from surveys made by Capt. Owen \& Lieut. Herbert, R.N., and Capt. A. Ford, U.S.N. [I866 printing] NMC vI/ 4Io-Ontario-I866 OTAR

City of Toronto. Compiled from surveys made to the present date, I866.

Lithographed, printed \& published by W.C. Chewett \& Co. NMC vI/ 440-Toronto-I866 OTAR

Enlarged Plan of the Combatants and Those Who Fell in the Skirmish, June 2nd, 1866. NMC B/440-Limeridge-I866 (from The Fenian Raid at Fort Erie, June the First and Second, Chewett, I866)

McMillan's New Map for May, 1866: Map of the Oil Regions, in the Vicinity of Bothwell, C.W., May, 1866. Murdock, Hanning, Peterson \& Brodie, Civil Engineers \& P.L. Surveyors, Oak Street, Bothwell, C.W. NMC H2/400-I866 (not seen)

Map Illustrating the Fenian Raid, June 2nd,1866. Published by W.C. Chewett \& 
Co. NMC B/407-I866 (from The Fenian Raid at Fort Erie ...)

Plan of the North Shore of Lake Superior, 1866. Department of Crown Lands.

The Honorable Alex. Campbell, Commissioner. NMC H2/4IO-Superior-

I866 (not seen)

That Part of Canada Now Invaded by Fenians, June 2nd, 1866. NMC

F/400-I866 (not seen)

1867

Map of the Confederate Provinces of British North America, Engraved

Expressly for the Canadian Almanac, 1867. Published by W.C. Chewett \& Co. NMC HI2/IIOO-I867 OTAR

Map of the Town of Galt, County of Waterloo. Compiled for the Corporation by James Pollock, Provincial Land Surveyor. NMC vi/440-Galt-I867 (facsimile only; not seen)

1868

City of Toronto. Compiled from surveys made to the present date, I 868 .

Lithographed, printed \& published by W.C. Chewett \& Co. OTAR

Map of the Dominion of Canada, Engraved Expressly for the Canadian

Almanac, 1868. Published by W.C. Chewett \& Co. OTAR

Plan of Wine Harbour Gold District, Shewing the Block Belonging to the Eureka Gold Mining Company of Nova Scotia. Halifax, N.S., 21 Jany, 1868. NMC H3/219-Wine Harbour-r868 (not seen)

1869

Map of the Town of Brantford, in the County of Brant, Province of Ontario, Canada. NMC HI/440-Brantford-I 869 (not seen)

\section{UNDATED}

Map of the Beavermead Property at Peterborough, C.W. Formerly the Property of the Late Judge Hall.... NMC H2/44O-Peterborough-[n.d.] OTAR

Plan of Dudley in the County of Peterborough, Canada West. The Property of the Canadian Land et Emigration Company [Limited] of London, England. NMC H2/43O-Dudley-[n.d.] (not seen)

Plan of Dysart, County of Peterborough, Canada West. The Property of the Canadian Land \&) Emigration Company [Limited] of London, England. NMC H2/43O-Dysart-[n.d.] (not seen)

Plan of Harburn, County of Peterborough, Canada West. The Property of the Canadian Land et Emigration Company [Limited] of London, England. NMC H2/43O-Harburn-[n.d.] (not seen)

Plan of Havelock, County of Peterborough, Canada West. The Property of the Canadian Land et Emigration Company Limited of London, England. 
NMC H2/430-Havelock-[n.d.] (not seen)

Plan of Part of Sherbrooke Gold District, Shewing Kingston Coy's Property.

NMC H3/4I9-Sherbrooke-[1870] (Dated I870 by NMC, but must have been printed earlier; not seen.)

Plan of Part of the Red River Route, Surveyed and Explored by S.J. Dawson and Party in 1858. NMC H3/409-Rainy River-I858 OTAR (Although the survey was made in 1858 , this map, which bears a Chewett $\&$ Co. imprint, must date from the r86os.)

Plan of the Nine Townships in the County of Peterborough, Province of Ontario. The Property of the Canadian Land et Emigration Company. NMC H2/42O-Peterborough-[pre-I875] (not seen)

[Southeastern Part of Haliburton County] N MC F/42O-Haliburton-[1874]

(Dated 1874 by NMC, but this map must also have been printed in the I86os; not seen.)

Town Plot of Haliburton, in the Township of Dysart, Canada West. The Property of the Canadian Land «) Emigration Company (Limited) of London, England. oT URs

\section{Section Four: Sheet Music}

(Imprint reads: W.C. Chewett \& Co., lith., Toronto. All of these examples were published by A. \& S. Nordheimer of Toronto; Chewett \& Co. produced only the lithographed covers.)

1866

The Old Piney Woods: Song e Chorus: March. 5 pp. OT McL ot Uf M Suddon The Welcome Galop; Dedicated to the 13th Hussars. [1866] 6 pp. Suddon

1867

Holt, J. La Crosse: Galop by J. Holt, Jr., B.M. 17th Regt. [1867] 7 pp. OT MCL Suddon

DATE UNCERTAIN

The Band: A Selection of Fashionable Dances for the Piano Forte. [A series published by A. \& S. Nordheimer during the I860s and I870s. Chewett \& Co. produced an elaborate cover for at least one part: Miller's Canadian Winter: Galop, 5 pp.] Suddon (See also Calderisi, p. 54, 56. )

Section Five: Broadsides and Ephemera

1863

City of Toronto Public Schools Certificate. [Dated 23 December I863] W.C.

Chewett \& Co., lith. OTMCL 
Presentation of a Silver Mace to the 2nd Battalion (Queen's Own) Volunteer Rifles, by Their Lady Relatives and Friends. Model School Grounds, Toronto, May 25th, 1863. [lithotint] Drawn and published by the Canada Engraving Establishment, 76 King St. East, Toronto, C.W.; W.C. Chewett \& Co., imp. OTMCL

1864

Notice to H.M. Pensioners. The Pensioners Who Have Been Paid at the Undernamed Stations, Are Required to Attend at the Usual Places as under. No Pensions Will Be Sent to Absentees, nor Paid to Any Man except at his Proper Station, unless on Medical Certificate, 'Unable to Attend.' Pensioners Must Attend Early on the Morning of the Day Fixed for Payment in This Occasion.... [signed] G.F. MacDonald, Captain, Staff Officer of Pensioners, Toronto District. Toronto, Ioth Sept., I864. OTMCL

1865

Toronto Harbour in 1820: Fac-simile of an Original Drawing by Sir Peregrine Maitland, K.C.B., Lieut. Governor of Upper Canada. W.C. Chewett \& Co., lith. [ca. I865] OTMCL

1866

Complimentary Promenade Concert in Honor of the Toronto Volunteers, at the Drill Shed, on the Evening of the Queen's Birth Day, 24th May 1866, at 8 o'clock. Admit One. (No. 957) James Harmon, Secretary. W.C. Chewett \& Co., lith. OTMCL

New English Reports. Toronto, 6th April, 1866... [broadside advertisement]

W.C. Chewett \& Co., agents for Upper Canada. OTMCL

1867

City of Toronto Public Schools Certificate. [Dated 2oth December I867] W.C.

Chewett \& Co., lith. OTMCL

1869

The Canadian Almanack for 1869. Toronto. W.C. Chewett $\Theta$ Co., Printers,

Lithographers, Booksellers, Stationers, Bookbinders, Engravers.

[advertisement in the form of a sheet almanac] OTAR

UNDATED

Farms and Wild Lands For Sale... For Price and Terms Apply to W. Hope, Land Agent and Broker, 2 Victoria Hall, Melinda Street, Toronto.... W.C. Chewett

\& Co., printers. OTMCL

50 Merits. Public Schools. Upper Canada. Diligence. W.C. Chewett \& Co., lith. OTMCL

50 Merits. Public Schools. Upper Canada. Good Conduct. W.C. Chewett \& 
Co., lith. OTMCL

50 Merits. Public Schools. Upper Canada. Perfect Recitation. W.C. Chewett \& Co., lith. OTMCL

50 Merits. Public Schools. Upper Canada. Punctuality. W.C. Chewett \& Co., lith. OTMCL

Summons to Defendant. [Magistrates' Blank] Form no. I8o. W.C. Chewett \& Co., law publishers. OTMCL

Summons to Witness. [Magistrates' Blank] Form no. I82. W.C. Chewett \& Co., law publishers. OTMCL OTURS

Warrant of Commitment. [Magistrates' Blank] Form no. I8I. W.C. Chewett \& Co., law publishers. OTURS

Section Six: Company Trade Catalogues

1861

Catalogue of Illustrated Christmas and New Year Gift Books, 1861-2. I2 pp.

OTMCL

1863

W.C. Chewett \&) Co's Catalogue of Photographic Albums, Illustrated

Christmas and New Year Gift Books, etc., 1863-4. I2 pp. OT MCL

1864

W.C. Chewett e) Co's List of Medical Books, Session 1864-5. (First edition). 7

pp. OTMCL

1865

List of Books Used in Upper Canada College, Arranged according to Their

Respective Forms, for Sale by W.C. Chewett e) Co., Educational

Booksellers. W.C. Chewett \& Co.'s Catalogues, no. 5. 3 pp. OT MCL

To the Legal Profession. W.C. Chewett «) Co's List of Law Publications -

English and American, Imported and for Sale at 17 e) 19 King Street East,

Toronto. I 1. OTMCL

W.C. Chewett «) Co.'s Illustrated Catalogue of Presentation Books for the Season, Juvenile Books, Photographic Albums, etc., etc., etc., Christmas, 1865. 28 pp. OTMCL

1866

W.C. Chewett $\uplus$ Co.'s Christmas Catalogue of Illustrated Books for Presentation, Juvenile Books, Photographic Albums, etc. etc. etc., Christmas, 1866. 24 pp. OTMCL 
W.C. Chewett 4 Co.'s Christmas Catalogue of Illustrated Books, for Presentation, Juvenile Books, Photographic Albums, Christmas Cards, etc., Christmas, 1867. 27 pp. OTMCL

[W.C. Chewett \& Co. subscription advertisement for] The Chromolithograph: A Journal of Art, Literature, Decoration, and the Accomplishments [London, England] [I867?] 4 pp. OTMCL

1868

W.C. Chewett «) Co.'s List of English Newspapers, Periodicals, etc., for 1869. [I868] 8 pp. OTMCL

1869

W.C. Chewett e) Co's Catalogue of Educational Works, English and Classical Text Books, Atlases, etc. W.C. Chewett \& Co., Educational Book Room. 44 pp. OTMCL 


\section{Appendix Two: Employees of W.C. Chewett and Company, I859-I869}

(Based on the City of Toronto Tax Assessment Rolls for the Ward of St. Lawrence, I859-I869. The position of each employee is given from I86I on, and beginning in 1864 the age is also included. Lithographers are mentioned in I863 only, and curiously Charles Fuller, who joined the company about I862, appears never to have been listed.)

W.C. Chewett and Company, I7 \& I9 King Street East, Toronto

1859 (still officially known as Maclear and Company)

W.C. Chewett

W.W. Copp

H.J. Clark - income

W.M. Peterkin - income

Fred. Rogers - income

TOTAL 5 (including 3 'income')

1860 (still Maclear and Company)

\{W.C. Chewitt [sic]\}

\{W.W. Copp

H.J. Clark - income

W.M. Peterkin - income

TOTAL 4 (including 2 'income')

1861 (W.C. Chewett and Company)

\{W.C. Chewett

\{W.W. Copp $\}$

H.J. Clark - Clerk

W.M. Peterkin - Clerk

TOTAL 4 (including 2 clerks)

1862

\{W.C. Chewett

\{W.W. Copp

\{H.J. Clark\}

W.M. Peterkin - Book-keeper

Thos. W. Rawlinson - Clerk

James Evans - Porter

TOTAL 6 (including I book-keeper, I clerk, I porter) 
1863

\{W.C. Chewett

\{W.W. Copp $\}$

$\{$ H.J. Clark\}

W.M. Peterkin - Book-keeper

T.W. Rawlinson - Clerk

James Evans - Porter

W.E. Brabant - Printer

W. Henderson - Printer

Wm. Cullen - Printer

Fred. Fell - Printer

John Gannon - Printer

Thos. Parker - Printer

Arch. Davis - Printer

Henry Copp - Binder

Peter Ellerby - Binder

Wm. Willis - Binder

Rich. Waylins - Binder

Wm. Innis - Binder

Lewis Ennecker - Lithographer

Wm. Dye - Lithographer

Dan Denyer - Lithographer

Henry Faust - Lithographer

Rudolph Otto - Lithographer

Valentine Schrieber - Lithographer

TOTAL 24 (including I book-keeper, I clerk, I porter, 7 printers, 5 binders,

6 lithographers)

1864

$\{$ William C. Chewett (age 35)\}

$\{$ William W. Copp (37)\}

\{Henry J. Clark (40)\}

W.M. Peterkin (30) - Book-keeper

T.W. Rawlinson (30) - Clerk

Thomas Hayes (26) - Porter

Walter Copp (18) - Clerk

John Gannon (46) - Printer

William E. Brabant (46)-Printer

Fredrick Fell (40) - Printer

William Cullen (38) - Printer

William Henderson (32) - Printer

William Willis (26) - Bookbinder 
William Innis $(24)-$ Bookbinder

Peter Ellerby (54)-Bookbinder

Daniel Hick (I9)-Bookbinder

Henry Copp (33)-Bookbinder

James A. Stephens (32)-Bookbinder

TOTAL I8 (including I book-keeper, 2 clerks, I porter, 5 printers,

6 bookbinders)

1865 (ages given for new employees only)

William C. Chewett

\{William W. Copp

\{Henry J. Clark\}

William M. Peterkin - Book-keeper

Thomas W. Rawlinson - Salesman

Thomas Hays - Porter

Walter Copp -

William E. Brabant - Foreman

Isaac Gunn (3I) - Printer

Thomas Parker $(22)$ - Printer

John Burns (33) - Printer

Fredrick Fell - Printer

William Cullen - Printer

William Henderson - Printer

John Gannon - Printer

Edward Hill (25)-Bookbinder

John F. Manning (2I) - Bookbinder

Peter Ellerby - Bookbinder

James A. Stephens - Bookbinder

Henry Copp - Bookbinder

Peter John Costello (25) - Pressman

Arch. Davis (44)-Pressman

TOTAL 22 (including I book-keeper, I salesman, I porter, I foreman printer, 7 printers, 5 bookbinders, 2 pressmen)

1866

William C. Chewett

$\{$ William W. Copp $\}$

$\{$ Henry J. Clark\}

William M. Peterkin - Book-keeper

Thomas W. Rawlinson - Salesman

Frances Nesbitt $(26)-$ Salesman

Walter B. Copp - Salesman 
Thomas Hays - Porter

William E. Brabant - Foreman Printer

Robert John Milligan (29) - Printer

Samuel Parker (I9) - Printer

Isaac Gunn - Printer

Thomas Wilson (48) - Printer

Fredrick Fell - Printer

William Cullen - Printer

William Henderson - Printer

De Vere Hunt (38) - Printer

John Gannon - Printer

John F. Manning - Bookbinder

Edward Hill - Bookbinder

John Morgan (50) - Bookbinder

Daniel Hick - Bookbinder

John Walters (40) - Bookbinder

Henry Copp - Bookbinder

James Stephens - Bookbinder

Thomas McKay (42)-Printer

TOTAL 26 (including I book-keeper, 3 salesmen, I porter, I foreman printer,

Io printers, 7 bookbinders)

1867

\{William C. Chewett

$\{$ William W. Copp $\}$

$\{$ Henry J. Clark

Thomas W. Rawlinson - Clerk

Francis Nesbitt - Clerk

Walter B. Copp-Book-keeper

Thomas Hayes - Porter

Robert Roberts (35) - Pressman

William E. Brabant - Foreman

Maurice Grand (I9) - Apprentice

John Gannon - Printer

John H. Jones (58)- Printer

De Vere Hunt - Printer

William Cullen - Printer

William Henderson - Printer

Thomas Wilson - Printer

Fredrick Fell - Printer

Thomas McKay - Pressman

Edward Hill - Bookbinder 
Daniel Hick - Bookbinder Henry Copp - Bookbinder

Peter Ellerby - Bookbinder

John Walters - Bookbinder

John F. Manning - Ruler

Isaac Gunn - Printer

Henri S. Smith (40) - Bookbinder

TOTAL 26 (including 2 clerks, I book-keeper, I porter, 2 pressmen, I foreman printer, I apprentice printer, 8 printers, 6 bookbinders, I ruler)

1868

\{William C. Chewett

$\{$ William W. Copp $\}$

\{Henry J. Clark\}

Thomas W. Rawlinson - Clerk

Frances Nesbitt - Clerk

W.B. Copp - Clerk

Thomas Hays - Porter

Robert Roberts - Pressman

William E. Brabant - Foreman

Thomas McKay - Pressman

Alfred Harcourt (23)-Printer

William Douglass (24)-Printer

Maurice Grand - Apprentice

John Gannon - Printer

William Cullen - Printer

Thomas Wilson - Printer

Fredrick Fell - Printer

De Vere Hunt - Printer

Isaac Gunn - Printer

H. Copp - Bookbinder

Peter Ellerby - Bookbinder

John Walters - Bookbinder

Henri Smith - Bookbinder

Edward Hill - Bookbinder

John Antonia (25)-Bookbinder

John Morgan - Bookbinder

Francis Brooks (I9) - Ruler

John F. Manning - Ruler

TOTAL 28 (including 3 clerks, I porter, 2 pressmen, I foreman printer,

I apprentice printer, 8 printers, 7 bookbinders, 2 rulers) 
1869 (Chewett bought out by Copp and Clark; name changed to Copp, Clark and Company)

\{William W. Copp

$\{$ Henry J. Clark\}

Thomas W. Rawlinson - Clerk

Frances Nesbitt - Clerk

W.B. Copp - Clerk

Henry Hartley (2I)-Clerk

William E. Brabant - Foreman

Masculine Allan (22) - Printer

John Gannon - Printer

H. Copp - Bookbinder

Henri Smith - Bookbinder

John Manning - Bookbinder

Joseph Patterson (26)-Bookbinder

Edward Hill - Bookbinder

TOTAL I4 (including 4 clerks, I foreman printer, 2 printers, 5 bookbinders) 